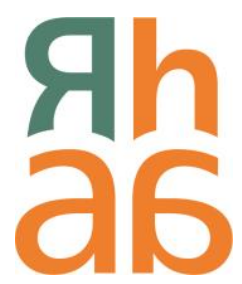

\title{
Crédito, deudas y obligaciones en la Gobernación del Tucumán: Salta, 1760 - 1776
}

\section{Credit, Debts and Obligarions of the Tucuman Governorate: Salta 1760-1776}

\author{
Marcelo Gabriel Anachuri \\ Universidad Nacional de Salta \\ Facultad de Ciencias Económicas, Jurídicas y Sociales \\ Facultad de Humanidades \\ Salta, Argentina \\ gabrielanachuri2016@gmail.com
}

\begin{abstract}
Resumen
En los últimos años la historiografía económica regional ha demostrado que, en Salta, al igual que otras ciudades hispanoamericanas, el crédito dinamizó las actividades comerciales y productivas más relevantes de la época. Estos estudios se centraron particularmente en las últimas tres décadas del período virreinal previo al estallido revolucionario. El presente artículo contribuye con estos recientes estudios al avanzar sobre las dinámicas estructurales y relacionales de la práctica crediticia notarial entre 1760 y 1776 , período en el cual Salta aún formaba parte de la Gobernación del Tucumán. Un período inédito para el problema abordado, signado
\end{abstract}

${ }^{1}$ El artículo forma parte del proyecto 2.340 del Consejo de Investigación de la Universidad Nacional de Salta (ClUNSa) en el cual el autor se desempeña como becario doctoral y del Instituto de Investigaciones Históricas Manuel Belgrano, Facultad de Artes y Ciencias, Universidad Católica de Salta. Agradezco las observaciones, comentarios y sugerencias realizadas por las/los evaluadores/as para mejorar la versión preliminar. Se deja claro que, cualquier error, vacío y/o confusión es de nuestra propia responsabilidad.

Cómo citar este artículo/ How to cite this article: Anachuri, M. G. (2021). Crédito, deudas y obligaciones en la Gobernación del Tucumán. Salta, 1760-1776. Revista de Historia Americana y Argentina, 56 (1), pp. 63-102. https://doi.org/10.48162/rev.44.002 
por convulsionados sucesos políticos, civiles y cambios institucionales que desembocarían años más tarde, en su nombramiento en capital de Intendencia de Salta del Tucumán. El relevamiento de las deudas formalizadas en obligaciones de pago en los libros de escribanos existentes en el Archivo Histórico de Salta junto con la elaboración de series, el análisis relacional y la reflexión historiográfica permitirán analizar las características, relevancia e incidencia que le cupo al crédito en la vida económica y social de esta comarca virreinal.

Palabras claves: Crédito; Fiscalidad; Comercio; Salta; Siglo XVIII.

\begin{abstract}
In recent years regional economic historiography has shown that, like other Latin American the cities, in Salta, credit in its various forms, invigorated the most important of the time commercial and productive activities. These studies focused particularly on the last three decades of the viceregal period prior to the revolutionary outbreak. The purpose of this article is to contribute to these recent studies as it progresses on the structural and relational dynamics of the notarial credit practice in Salta between 1760 and 1776, at which time it was still part of the Government of Tucumán. A unprecedented period for the problem addressed, marked by convulsed political and civil events and institutional changes that would lead years later, in its appointment as the capital of the Municipality of Salta del Tucumán. The survey of the debts formalized in payment obligations in the books of notaries existing in the Historical Archive of Salta together with the preparation of series, relational analysis and historiographic reflection are the theoretical and methodological tools that are used, and that allow to analyze the characteristics, relevance and impact that credit quota to the economic and social life of this colonial district.
\end{abstract}

Key words: Credit; Taxation; Commerce; Salta; Century XVIII.

Recibido: 8/04/2020. Aceptado: 29/05/2020

A mediados del siglo XVIII Salta empezaba a posicionarse en uno de los nodos políticos y comerciales más importantes del Tucumán virreinal. Articuló dos polos de gravitación regional y global. Al norte, casi a $800 \mathrm{~km}$ y un viaje que duraba aproximadamente dos meses, se hallaba Potosí, centro minero del cual se extrajo la plata que circuló a economías europeas y asiáticas (Flynn y Giráldez, 1995; 2002; Marichal, 2017, pp. 37-76; Bonialian y Hausberger, 2018). Al sur, a $1.480 \mathrm{~km}$ y a casi tres meses de travesía se hallaba Buenos Aires, que por entonces afianzaba su posición como un centro portuario gravitatorio ante las transformaciones causadas por la naciente industrialización inglesa, la cual incidió cabalmente en el

RHAA v. 56 n.1, 2021. ISSN: 0556-5960, ISSNe 2314-1549. CC BY-NC-SA 4.0 
protagónico rol que empezó a tener la plaza bonaerense y constituirse en capital del flamante virreinato del Río de la Plata desde 1776 (Camarda, 2015; Jumar, 2018).

Aquella prosperidad comercial derivó en una intensa escrituración legal de deudas formalizadas en obligación de pago ante los escribanos locales. A través de estos contratos notariales, el deudor reconocía la deuda y se obligaba "a dar y pagar llanamente y sin pleito alguno" a su acreedor, ante notario y testigos presentes. A pesar de la existencia de una diversidad de instrumentos escritos en la época para registrar deudas, desde mediados del siglo XVIII, las obligaciones de pago ya constituían el principal instrumento notarial crediticio empleado (Peña Mir, 2013; Wasserman, 2018b, p.167).

Por sus características notariales, el relevamiento de estas fuentes permite reconstruir y analizar montos prestados, destino del préstamo, plazos estipulados, garantías exigidas, tasas de interés, distribución espacial, fecha del contrato y de la cancelación, nombre del deudor, acreedor, residencia, ocupación, intitulación, fiadores, escribanos, testigos de la operación, etcétera. Al igual que otras sociedades contemporáneas, en esta sociedad salteña de Antiguo Régimen las redes interpersonales cobraron relevancia para la configuración de negocios, firma de contratos y compromisos crediticios (Moutoukias, 1996; 2015; Barriera y Tarrago, 2000; Barriera, 2002; Wasserman, 2014; 2018á; 2018b; 2019; 2020; Del Valle Pavón, Ibarra y Alcántara, 2017; Quintanar, 2017, p. 157-199; Bertrand y Moutoukias, 2018, pp. 1-24).

A pesar de que recientes estudios señalaron la incidencia y relevancia del crédito notarial en la dinámica comercial, su efecto multiplicador de las riquezas y la generación de vínculos que integró a los actores en dinámicos entramados relacionales, estos trabajos se enfocaron en las últimas tres décadas del período virreinal (Mata, 1996; 2000; Conti, 2005; Conti y Gutiérrez, 2009; p. 45-47; Anachuri, 2019a; 2019b; 2019c; 2020, Wasserman y Anachuri, 2019). Con base en la información provista por las obligaciones de pago, resguardadas en la sección notariales del Archivo Histórico de Salta (en adelante AHS) el presente artículo tiene como propósito contribuir a estas recientes investigaciones en la medida que avanza sobre los principales elementos estructurales y relacionales de la práctica crediticia notarial en Salta entre 1760 y 1776, momento en el cual, ésta, aún formaba parte de la Gobernación del Tucumán. Constituye aún un período inédito para el problema abordado, signado por una serie de 
procesos políticos e institucionales, como las campañas ofensivas sobre la frontera oriental del Chaco Gualamba y la expulsión de la Compañía de Jesús, considerado uno de los primeros grandes cambios que tuvo el reformismo borbónico en la región la Gobernación del Tucumán (Lorandi, 2008; Giménez López, 2019)². Tendrían, desde luego, su correlato sobre las principales dinámicas de la práctica crediticia.

\section{La dinámica del crédito notarial y sus obligaciones contractuales en Salta 1760-1776}

La Gobernación del Tucumán formaba parte del Virreinato del Perú y jurídicamente estaba incluida en el distrito de la Audiencia de Charcas. Componían esta gobernación las ciudades de San Salvador de Jujuy, Salta, San Miguel de Tucumán, Santiago del Estero, Catamarca, La Rioja y Córdoba. El centro político y administrativo fue Santiago del Estero, allí se estableció la residencia del Gobernador y sede del obispado. Avanzado el siglo XVII, su decadencia impulsó el traslado de la sede episcopal a Córdoba en tanto el gobernador empezó a residir en Salta, constituida desde 1700 en capital de la Gobernación (Aramendi, 2020, p. 435-483).

El breve período histórico que nos ocupa, iniciado en 1760 y concluido en 1776, se caracterizó por pugnas y parcialidades que dividieron a los miembros de la élite local, derivadas por ambiciones de figuración social, luchas entre facciones políticas, ideológicas y corporativas y campañas ofensivas sobre el Chaco Gualamba. Funcionarios y vecinos de Salta impulsaron una política de "pacificación" y ocupación de los territorios orientales, adentrándose en el denominado Chaco Gualamba, un espacio en el cual convivían diversos pueblos indígenas con estancieros, sacerdotes y militares además de refugiados, milicianos, comerciantes y reos que burlaron la justicia de variada condición social y étnica (Mata, 2005, p. 7071). La avidez por los recursos humanos y materiales que implicó la movilización hacia la frontera oriental del Chaco Gualamba junto a las políticas borbónicas que persiguieron acrecentar los ingresos de las arcas reales, derivaron en una imperiosa necesidad por parte de los sucesivos gobernadores de aumentar, controlar y efectivizar la recaudación fiscal.

\footnotetext{
${ }^{2}$ Respecto al grado de representatividad del muestreo hay que anticipar al lector/a que la serie de protocolos notariales para los años de 1761-62-66 no se encuentra en el Archivo Histórico de Salta (AHS).
}

RHAA v. 56 n.1, 2021. ISSN: 0556-5960, ISSNe 2314-1549. CC BY-NC-SA 4.0 
A pesar de las dificultades derivadas del contexto endeble, la economía demostró ser bastante activa desde la segunda mitad del siglo XVIII. Después de Córdoba, fue la segunda ciudad en importancia de todo el Tucumán virreinal; cabeza de la futura Intendencia de Salta del Tucumán, lo que muestra claramente su peso en el contexto regional (Fradkin y Garavaglia, 2016, pp. 65-68). Respecto de otras ciudades de la región (Tarija, Jujuy, Tucumán, Catamarca, Santiago del Estero y el distrito de la Puna) fue la que registró mayor actividad comercial (Acevedo, 1965, pp. 223-318; Mata, 2000, pp. 27-52; Anachuri, 2019b).

En esta sociedad salteña virreinal, similar a otros espacios hispanoamericanos, con fronteras permeables, población móvil, envuelta en permanentes conflictos intraoligárquicos, donde la ilegalidad de los tratos representaba un riesgo para quienes debían operar por fuera de redes interpersonales confiables, "la construcción del crédito resultaba tan compleja como fundamental" (Wasserman, 2018b, pp. 167-187). El crédito contribuyó, así, al despliegue de las actividades comerciales y productivas más relevantes de esta comarca, en un contexto hostil que implicaba afrontar considerables riesgos.

Entre 1760 y 1776 el relevamiento y análisis de los protocolos notariales arrojó 367 cartas de obligación y/o obligación de pago sobre la totalidad de protocolos notariales. Las mismas acreditaron sumas por \$1.511.969 pesos corrientes de a ocho reales. Las operaciones crediticias en Salta se caracterizaron por movilizar mayores volúmenes de dinero en comparación a otras ciudades hispanoamericanas. Por ejemplo, María Eugenia Horvitz Vázquez (1966) estimó que, en Santiago de Chile, cabecera de la Capitanía General de Chile, entre 1759 y 1776 se formalizaron 433 cartas de obligación, las cuales movilizaron valores correspondientes por \$ 919.032. El promedio anual general en los volúmenes acreditados a través de obligaciones de pago en Salta duplicó al de Santiago de Chile. Alcanzó los \$ 116.305 mientras que en la plaza santiaguina rondó en \$ 57.439. Los volúmenes transferidos a través de estos instrumentos de préstamos en Salta continúan siendo significativos en comparación con otros indicadores fiscales. En el mismo período las alcabalas recaudaron $\$ 60.318$.

El universo de actores involucrados en la actividad crediticia se conformó por 357 varones y mujeres. Algunos sólo participaron como prestamistas, otros tanto sólo como deudores. Fueron escasas las personas que ocuparon ambos roles, lo cual explica los 178 deudores y 179 acreedores. Si tomamos los datos poblacionales de Comadrán Ruiz (1969) quien calculó

RHAA v. 56 n.1, 2020. ISSN: 0556-5960, ISSNe 2314-1549. CC BY-NC-SA 4.0 
la población urbana de Salta en 4.020 habitantes, podemos plantear que el préstamo notarial constituyó una práctica socioeconómica circunscripta a un reducido grupo con capital relacional y material identificable, algo de lo que carecía la mayoría de los habitantes de la comarca (p. 50). De acuerdo con estos datos poblacionales, el $8,88 \%$ de la población local urbana participó en la actividad crediticia notarial.

Como apreciamos en el cuadro $\mathrm{n}^{\circ} 1$, las sumas acreditadas a través de estos instrumentos tendieron a superar los $\$ 1.000$ (87,2\% de las escrituras oscilaron entre los $\$ 1.000$ y $\$ 10.000$ pesos corrientes de a ocho reales), seguidas por aquellas en las que fueron acreditados entre \$101 y \$500 (en general estas cifras ocuparon el $10,4 \%$. Por último, se ubican los compromisos crediticios que superaron $\$ 10.000$ (2,5\% de las escrituras).

Cuadro $n^{\circ}$ 1: Obligaciones contractuales de crédito. Sumas transferidas por compromiso, Salta $1760-1776$

\begin{tabular}{ccc}
\hline Suma transferidas & \% operaciones & cantidades de transacción \\
\hline $\mathbf{1}$ a $\mathbf{1 0 0}$ & 0,0 & 0 \\
$\mathbf{1 0 1}$ a 500 & 3,3 & 12 \\
$\mathbf{5 0 1}$ a $\mathbf{1 0 0 0}$ & 7,1 & 26 \\
$\mathbf{1 0 0 1}$ a $\mathbf{5 0 0 0}$ & 67,8 & 249 \\
$\mathbf{5 0 0 1}$ a $\mathbf{1 0 0 0 0}$ & 19,3 & 71 \\
$\mathbf{1 0 0 0 1}$ a $\mathbf{2 0 0 0 0}$ & 1,4 & 5 \\
más de $\mathbf{2 0 0 0 0}$ & 1,1 & 4 \\
Total & 100,0 & 367 \\
\hline
\end{tabular}

Fuente: AHS, Sección notariales, protocolos número 122 a 145,147. Cajas 10-13.

La preeminencia de montos prestados entre $\$ 1.000$ y $\$ 10.000$ corrobora que las obligaciones de pago se destinaron principalmente para financiar actividades comerciales y productivas. El 69\% del conjunto de los préstamos se destinaron al envío de mulas al Alto Perú y adquirir y/o redistribuir los efectos de Castilla provenientes del comercio transoceánico 
(cuadro $\mathrm{n}^{0}$ 2). Estos porcentajes ratifican que, la actividad crediticia notarial cumplió una función clave en la dinámica económica local, para movilizar la producción, el comercio mular y las mercaderías de ultramar. En efecto, constituyó un elemento central que dinamizó las principales actividades económicas de la época.

Cuadro n 2: Destinos explicitados del crédito notarial. Salta 1760-1776

\begin{tabular}{lll}
\hline Objeto del crédito & Participación \% & Número de obligaciones \\
\hline Mulas / ganados & 43,87 & 161 \\
Préstamos monetarios & 26,43 & 97 \\
Efectos de Castilla & 25,07 & 92 \\
Liquidación de cuenta & 4,63 & 17 \\
\hline Totales & 100,00 & 367 \\
\hline
\end{tabular}

Fuente: AHS, Sección notariales, protocolos número 122 a 145,147. Cajas 10-13.

El promedio de montos acreditados se correlaciona al dinero requerido para circular tropas de mulas a las plazas altoperuanas. Según Sánchez Albornoz (1965) cada mula valió entre $\$ 4$ y $\$ 12$. En promedio, las partidas de ganado mular se compusieron de 500 a 1.000 mulas, por lo que se necesitaba entre \$2.500 y \$ 7.000 para afrontar los costos de su adquisición y tránsito. Tal es el caso de los $\$ 6.578$ por el cual se obligaron Valentín Angulo, vecino y comerciante de Córdoba, y Joseph Arias Rengel, vecino de Salta, a favor de Andrés del Delgado, vecino de Salta, procurador de provincia y director del colegio de la Compañía de Jesús, procedidos "del valor de quinientas y seis bestias mulares que me ha vendido a mi el dicho Valentín a tres pesos por cabeza" 3 .

El crédito notarial también otorgó los engranajes financieros fundamentales sobre los cuales se apoyó la circulación local y regional de efectos de Castilla que, desde aquellos años ingresaron con mayor frecuencia a través de Buenos Aires. Por ejemplo, el 2 de noviembre de 1769, Phelipe Quiñonez y Bernardo Pérez, vecinos y comerciantes de Salta, se obligaron

\footnotetext{
${ }^{3} \mathrm{AHS}$, Sección notariales, protocolo núm. 122, Carpeta 10, Fs. 44 v. Los deudores se comprometieron rescindir el préstamo en cinco meses, poniendo por especial hipoteca a las mismas mulas. Finalmente se canceló el 13 de febrero de 1761.
}

RHAA v. 56 n.1, 2020. ISSN: 0556-5960, ISSNe 2314-1549. CC BY-NC-SA 4.0 
por $\$ 2.464$ y seis reales, a favor de Francisco Maurín, comerciante y vecino de la plaza local, procedidos:

(...) del resto del valor de una memoria de efectos de Castilla que por orden de dicho don Francisco Maurín, se me entregaron en la Ciudad, y puerto de Buenos Aires, á mi el dicho Quiñones en el mes de Abril del año próximo pasado de sesenta y ocho, de cuenta del expresado Don Francisco ${ }^{4}$.

La presencia de comerciantes de ciudades colindantes ratifica la importancia comercial y financiera que ya detentaba Salta en relación a las demás ciudades y las posibilidades que ofrecía para realizar buenos negocios. El 30 de julio de 1770 Antonio Zúñiga, vecino de Belén, Catamarca, formalizaba una obligación por \$2.167 a favor de Francisco Maurín, de Salta, cedidos en moneda doble y efectos de Castilla y de la tierra ${ }^{5}$. En menor porcentaje, otros préstamos se emplearon para cancelar liquidación de cuentas previas, algunas de las cuales provenían de la disolución de antiguas compañías mercantiles. Es el caso de la obligación formalizada el 17 de diciembre de 1760 por Juan Vidart de Linares, vecino y comerciante de Salta, por \$1.355 a favor de Agustín de Zuviria, cedidos por "liquidación de cuentas de la compañía que tuvimos y hemos traído en razón de efectos de Buenos Aires"6.

Aunque con fluctuaciones marcadas a lo largo del período, el promedio anual de los fondos movilizados mediante estos instrumentos crediticios en Salta demostró una tendencia creciente a medida que se avanzaba hacia la década de 1770. Los mismos se caracterizaron por montos significativos y superaron en promedio al de otros espacios pertenecientes a la Monarquía Hispánica 7 . El rango de \$1.000 a \$ 5.000 constituyó una línea de flote $(74 \%$

\footnotetext{
${ }^{4}$ Los deudores se comprometieron a cancelar el préstamo durante marzo de 1770. AHS, Sección notariales, protocolo núm. 131, Fs. 8 v.

${ }^{5} \mathrm{El}$ deudor se comprometió cancelar el contrato crediticio en el término de doce meses. En "burros invernados y aptos para caminar a las Provincias del Perú de edad de cuatro para cinco años". AHS, Sección notariales, protocolo núm. 134, Caja 12, Fs. 222 r.

${ }^{6}$ AHS, Sección notariales, protocolo núm. AHS, Sección notariales, protocolo 122, caja 10, Fs. 333 r.

${ }^{7}$ No contamos hasta el momento con series de salarios y precios relativos para la Salta tardía-virreinal. Pueden exponerse algunos datos, para precisar una idea global, del alcance de los montos otorgados a través de préstamos por estas mujeres. Entre 1796 y 1803, el gobernador y capitán general, máxima autoridad

RHAA v. 56 n.1, 2021. ISSN: 0556-5960, ISSNe 2314-1549. CC BY-NC-SA 4.0
} 
del total de compromisos). Tal como puede apreciarse en gráfico ํo 1 , en el período 1772-1776 las sumas medias prestadas anualmente por obligaciones de pago superaron con creses la media móvil de la década de 1760. La dispersión se sostuvo y amplificó en esos años por la reactivación de los circuitos comerciales transregionales.

El pago de una obligación constituía su cumplimiento, con lo cual, el deudor principal, sus fiadores y sus herederos quedaban liberados de la obligación personalmente asumida por el primero. A la extinción de la obligación personal y sus posibles garantías reales, le correspondía la carta de pago, la cual podía aparecer como documento independiente o como una nota al margen que cancelaba la escritura de obligación (Wasserman, 2018b, p. 175).

En Salta, estos instrumentos crediticios solían rescindirse en el mediano a corto plazo. El 55,04 \% de las cartas de obligación procuraron cancelarse en doce meses. El 37,33\% en un término menor a los 12 meses. Dentro del porcentaje restante del $7,63 \%$ encontramos préstamos, cuya duración fueron desde los 13 a 48 meses $^{8}$. Los plazos acordados en la mayoría de

política de la Intendencia, tenía un salario anual de \$3.814 y \$288 mensuales, el cual se mantuvo sin mayores fluctuaciones a lo largo de estos lustros. Un teniente asesor obtenía al año \$1.500 y \$ 222 mensuales, el tesorero \$279, el contador \$ 270 al mes. El sueldo mensual de un oficial mayor osciló, entre esos años, de $\$ 180$ a \$ 300. La desigualdad salarial respecto a escalas inferiores en las jerarquías de oficios fue muy considerable. Los escasos datos informan que, por ejemplo, el vidriero de la Aduana obtenía \$ 48 mensuales y el viñatero \$13 (AHS, Sección Hacienda, Libro № 189 "Cuentas de empleados. 1796-1802". Caja núm. 2). La práctica del endeudamiento se extendió a todos los oficios, aunque la finalidad de los préstamos solicitados varió de acuerdo al capital disponible y las necesidades inmediatas. Desde luego que un vidriero o viñatero no se endeudaba para suplir sus actividades comerciales, sino más bien, necesidades básicas cotidianas como alimentarse ellos y sus familias. Según Acevedo (1965) un menú de tres platos, compuesto por carne, pan y arroz, podía alcanzar un costo de $\$ 10$ pesos diarios. La arroba de azúcar estaba a \$ 8, el arroz a \$2, un cordero en 1796 llegó a costar \$ 30, el precio de la coca, producto regional que alcanzó un consumo popular importante, llegó a costar entre 8 y 12 reales.

${ }^{8} \mathrm{~A}$ lo largo del periodo estudiado, el contrato crediticio que mayor dilatación temporal mostró en los plazos de cancelación fue acordado el 12 de mayo de 1766 por Gabriel Torres, vecino de Salta. Se obligó por \$10.000 a favor de Domingo Saravia y Aguirre, alférez real y vecino en la plaza local "me ha suplido y prestado por hacerme amistad y buena obra y confieso haber recibido a mi satisfacción y

RHAA v. 56 n.1, 2020. ISSN: 0556-5960, ISSNe 2314-1549. CC BY-NC-SA 4.0 
las obligaciones estuvieron determinados por las dilataciones temporales y coyunturales de la circulación local, regional y virreinal.

Gráfico $\mathrm{n}^{\circ}$ 1: Promedio anual de los montos de préstamos en Salta, 1760-1776

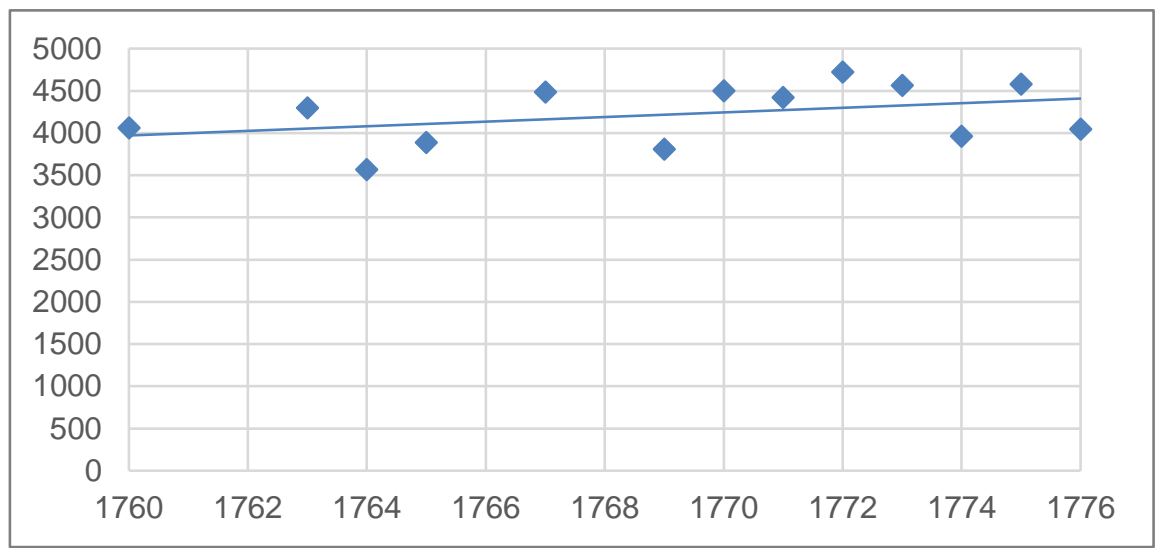

Fuente: AHS, Sección notariales, protocolos número 122 a 145, 147. Cajas 10-13.

En efecto, los términos del intercambio sostenido con base en el crédito se trastocaban ante situaciones de mayor incertidumbre y especulación. En los periodos de mayor riesgo los plazos del endeudamiento se acortaban. Como demostramos en el gráfico $\mathrm{n}^{\circ}$ 2, cuando se incrementaban las tensiones existentes contra las poblaciones afincadas en la dilatada frontera oriental chaqueña aumentaban los riesgos financieros, por lo cual, los plazos en el reintegro disminuían. Prácticamente, en toda la década de 1760 , los términos de cancelación promediaron los ocho meses. En ese decenio el gobernador Juan Manuel Campero realizó dos campañas muy exitosas que redujo a numerosos grupos indígenas (Lorandi, 2000, p. 325; 2008, pp. 38-58).

contento. El deudor se comprometió a "dar y pagar toda junta en esta ciudad dentro del término de cuatro años" con el interés del cinco por ciento anual. Finalmente, canceló el contrato el 14 de septiembre de 1771. AHS, Sección notariales, protocolo núm. 145, Carpeta 14, Fs. 49 v.

RHAA v. 56 n.1, 2021. ISSN: 0556-5960, ISSNe 2314-1549. CC BY-NC-SA 4.0 
Gráfico n²: Promedio anual en los plazos de cancelación (meses)

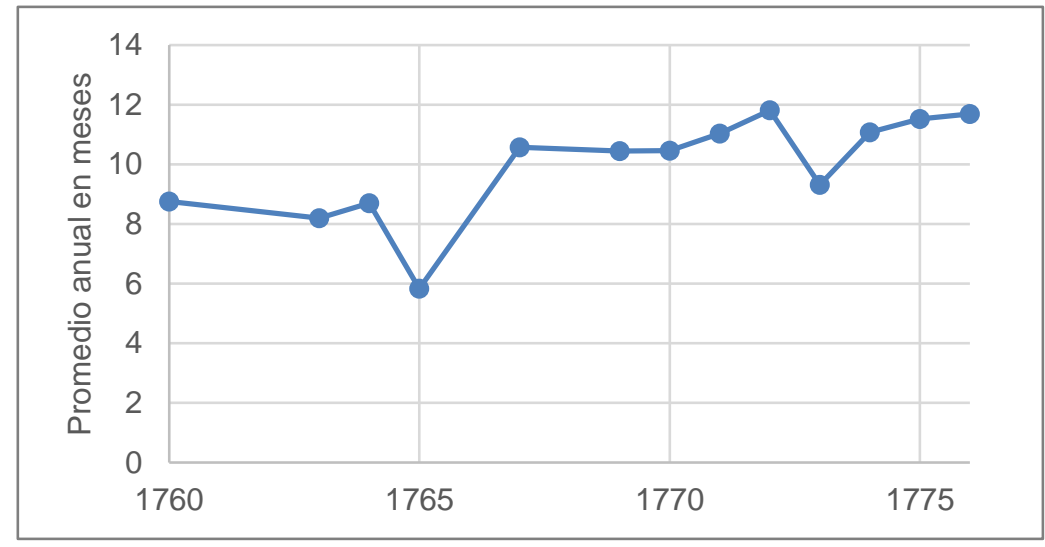

Fuente: AHS, Sección notariales, protocolos número 122 a 145,147. Cajas 10-13.

Al constituir los resortes fundamentales de financiamiento de las actividades comerciales y productivas, la temporada de escrituración de obligaciones de pago en Salta tendió a concentrarse en marzo $(42,5 \%$ sobre el total de compromisos) y abril (23,4\%). Esto confirma la relevancia de los préstamos notariales en la colocación de fondos para sostener los tratos y contratos asumidos en aquellos intercambios, desplegados en las tabladas de las inmediaciones a la Ciudad de Salta. El ritmo del comercio local, regional y transoceánico también determinó, en gran medida, los plazos de cancelación de las deudas notariales. Quienes se endeudaban en los meses feriales, aprovechaban el retorno de sus capataces con metálico del Alto Perú para rescindir sus contratos crediticios. Por ejemplo, el 30 de marzo de 1772, Juan Antonio González, comerciante y vecino de Salta, se obligó por \$ 1.026 a favor de Joseph Ignacio Zevallos "producidos de las mulas que me ha vendido invernadas y aptas para caminar á las Provincias del Perú y confieso haber recibido a mi entera satisfacción y de mis capataces". Al momento de establecer plazos y formas de reintegro, el deudor, expresó:

(...) como llano y verdadero deudor que soy y me constituyo de ella me obligo a dar y pagar remitiendosela de mi cuenta, costo y riesgo á esta Ciudad con mi Capatas Don Cayetano Aguirre a su regreso á ella, queserá en todo septiembre del corriente año, y en su defecto 
con derecho qualesquiera que rogase de la Tablada de Jauja en plata moneda doble $(\ldots)^{9}$.

Similar a otros espacios hispanoamericanos, el tránsito del Real Situado por Salta con destino a Buenos Aires, también constituyó un momento oportuno para cancelar deudas notariales. Situación que suma evidencia empírica a aquellos estudios que señalaron las intervenciones particulares y corporativas sobre los recursos fiscales de los fondos potosinos (Gelman, 1996; Wasserman, 2016). Es el caso de la obligación formalizada el 6 de agosto de 1773 por Gavino Quevedo y Manuel Abad por \$ 5.381 a favor de Antonio Pardo, vecino y comerciante de Salta. Al momento de establecer plazos y formas de cancelación, los deudores manifestaron:

(...) os obligamos a darsela y pagarsela en esta ciudad en plata sellada moneda corriente con advertencia que los dos mil pesos de ellos deberemos entregarle a la salida del proximo situado y el resto a los siete meses de la fecha en adelante $(\ldots)^{10}$.

Otro contrato que evidencia la relevancia que le cupo al Real Situado para las transacciones crediticias, fue la obligación formalizada el 1 de marzo de 1774 por Juan Alonso Arroyo por \$2.418, nuevamente, a favor de Antonio Pardo, cedidos en efectos de Castilla. Al momento de establecer plazos de reintegro, el prestatario se comprometió rescindir el crédito en cuotas. Los \$ 500 "para el primer situado que bajase de esta para la de Buenos Aires" y el saldo restante en seis meses.

Hallamos en Salta un universo de deudores con escasa propensión a la morosidad. En términos generales, cancelaron el 61,30\% (es decir 225 contratos registran su cancelación) sobre el total de obligaciones de pago. Aun así, la morosidad y la capacidad de reintegro variaron de acuerdo a las situaciones políticas y civiles atravesadas. Como puede apreciarse en el gráfico $n^{\circ} 3$, la morosidad creció durante los primeros años de la década de 1760 , y alcanzó su punto máximo en 1764 , con el $67 \%$ de las obligaciones contractuales sin rescindirse. A partir de 1772, se inició una fase decreciente que respondió, probablemente a la bonanza mercantil que atravesó la plaza salteña y a la mayor estabilidad política y social en la región. El incremento de la actividad comercial y la mayor comercialización en la región permitió a los tomadores de deudas cumplir con sus contratos

${ }^{9} \mathrm{AHS}$, Sección notariales, protocolo núm. 136, Carpeta 12, Fs. 72 v.

${ }^{10} \mathrm{AHS}$, Sección notariales, protocolo 138, Carpeta 13, Fs. $156 \mathrm{r}$.

RHAA v. 56 n.1, 2021. ISSN: 0556-5960, ISSNe 2314-1549. CC BY-NC-SA 4.0 
de crédito en tiempo y forma, y a los prestamistas aumentar sus fondos transferidos a crédito.

El promedio de contratos sin cancelarse entre 1770 y 1776 fue del $36 \%$, mientras que el periodo anterior (1760-1769) superó al $50 \%$ (véase gráfico $\mathrm{n}^{\circ} 3$ ). La variación relativa en el descenso de la morosidad entre una y otra etapa fue del -28\%. Algunas investigaciones (Moreno 2014; Gervais, 2012) sostienen que la fecha y forma de reintegro (incluida el periodo inicial sin interés) dependía del contexto y de la relación entre los consignatarios que implicaban tasas de usura oculta o por debajo del interés ética y moralmente admisible en los territorios de la Monarquía Hispánica del 5\% anual. Asimismo, rara vez los acreedores querían que la deuda se pagara antes de su vencimiento, a fin de obtener un saldo más alto que incluyera los intereses ${ }^{11}$.

Si la obligación de préstamo ya significaba una prueba contractual y una condición jurídicamente válida para reclamar el cumplimiento de una deuda, las características propias de una población móvil, envuelta en permanente conflictos facciosos y basada en lógicas consuetudinarias condujo a que las obligaciones de pago de los años analizados se respaldaran en una garantía material. La misma consistía en la mencionada cláusula de obligación general de bienes, según la cual el deudor comprometía su "persona y bienes habidos y por haber". Dicha garantía general sólo estaba reforzada por la cláusula de sumisión a las justicias y por la renuncia a los privilegios que le correspondiese a través de la cláusula de renuncia del

\footnotetext{
${ }^{11}$ En el caso de las deudas salteñas protocolizadas, el $60 \%$ registra interés en la misma escritura de obligación contractual. En la totalidad de aquellos compromisos que registraron el interés de la operación, el mismo se abonaba comúnmente en virtud del atraso y/o tardanza en los plazos de cancelación previamente acordado entre las partes. Desde la década de 1770, todas las transferencias registraron interés que osciló entre el $5 \%$ y $6 \%$ anual, no obstante, hallamos seis compromisos que registraron un interés anual del $8 \%$. Entre los acreedores de los contratos con ese interés y acreditaron las sumas más elevadas se destacan Juan Vidart Linares, vecino y comerciante de Salta, por un préstamo de \$9368 otorgado a Joseph Leigory, residente en Salta y vecino de Perú; Juan Joseph Zamudio y Miguel Antonio Fernández, ambos vecinos de Córdoba, por \$ 2834 a Bernardo Pérez, salteño, y Martín Almendariz, residente de Salta, quien otorgó un préstamo de $\$ 4300$ a Francisco Gavino Arias Rengel, maestre de campo y alcalde de $1^{\circ}$ voto de Salta y Juan Vidart Linares, suplidos por "Por otros tantos que por hacer bien y buena obra nos ha suplido en la misma especie de moneda". AHS, Sección notariales, protocolo 130, caja 11, Fs. 40 r; Fs. 41 v; 48 r.
}

RHAA v. 56 n.1, 2020. ISSN: 0556-5960, ISSNe 2314-1549. CC BY-NC-SA 4.0 
propio fuero y cláusula de renuncia a la invalidez de la renuncia general (Wasserman, 2018b, p. 178). La gran mayoría de las obligaciones de pago se garantizaron sólo con esta cláusula. Constituyeron el $81,33 \%$ de las operaciones y movilizaron el $85,11 \%$ del volumen total prestado. Entre las garantías materiales, la hipotecaria ocupó un papel significativo. Acumuló el $11,17 \%$ de las escrituras en total y movilizó el $15 \%$ del total de los valores prestados a través de compromisos de obligación. Como distinguimos en el gráfico $\mathrm{n}^{0} 4$, si bien en la mayoría de los años encontramos escrituras de préstamo que hipotecan garantías materiales (sea inmuebles, esclavos, productos, ganados, bienes, etcétera), el incremento de este tipo de operaciones se registra en los años de mayor intensidad de conflictos en la frontera oriental (1760-1771). Lo cual obedece al elevado nivel de riesgos que significaba operar en esos contextos y volvía inapelable para los acreedores contar con garantías más sólidas que resguardasen la cancelación del préstamo.

Gráfico $\mathrm{n}^{\circ}$ 3: Porcentaje de obligaciones contractuales no canceladas (1760-1776)

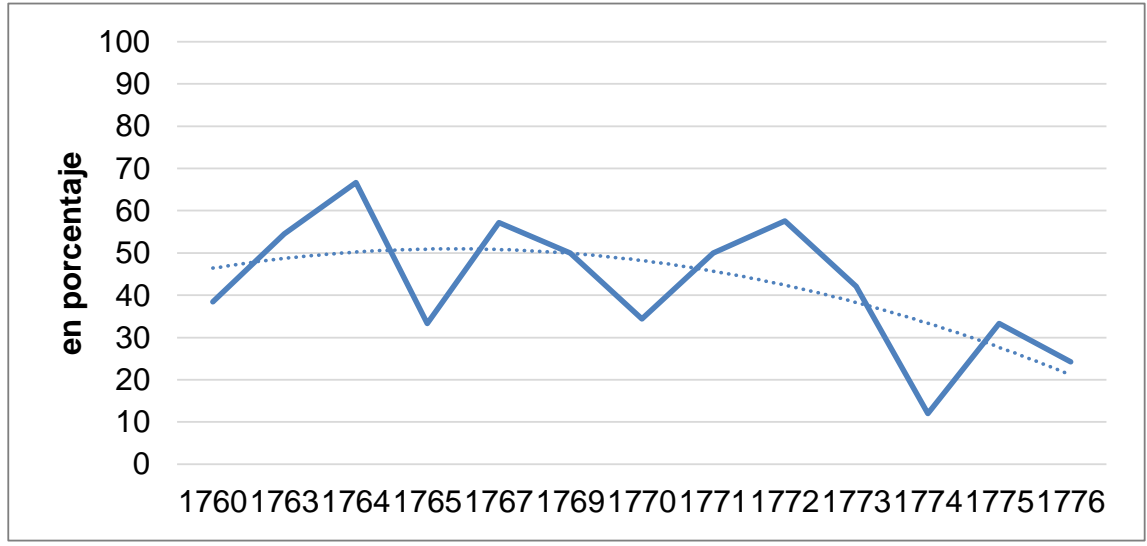

Fuente: Elaboración propia a partir de AHS, Sección notariales, protocolos número 122 a 144, 145,147. Cajas 10-13. Nota: se calculó el porcentaje de los compromisos no cancelados por cada año. 
Gráfico n 4: Escrituras con hipotecas materiales por año. Salta 1760 1776

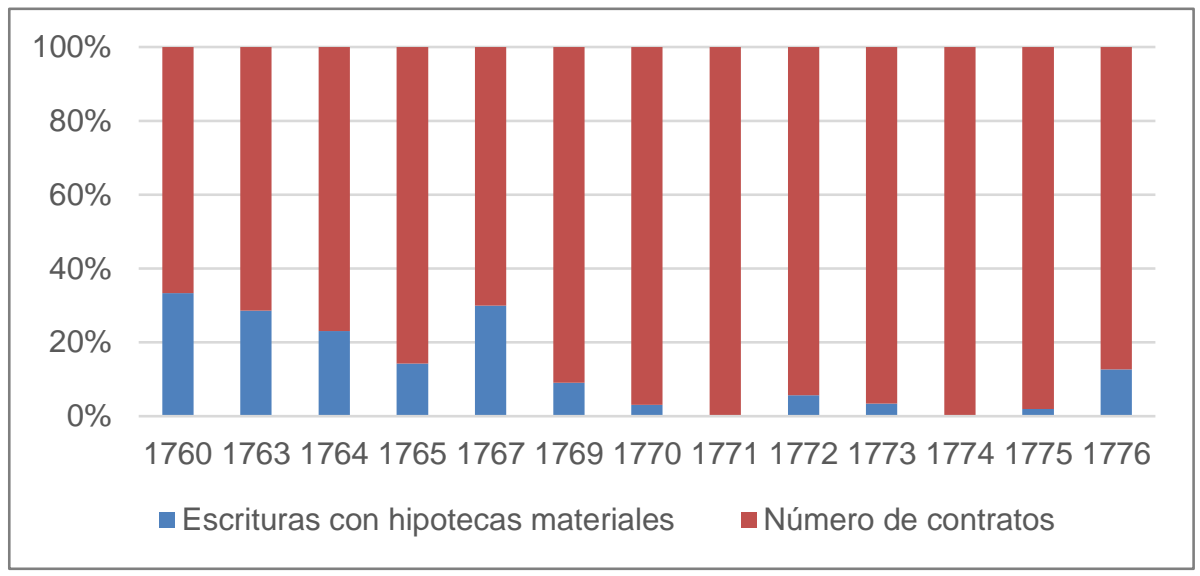

Fuente: Elaboración propia a partir de AHS, Sección notariales, protocolos número 122 a 145,147. Cajas 10-13. Nota metodológica: se calculó el porcentaje de los compromisos no cancelados por cada año.

Al momento de desagregar la calidad de las hipotecas materiales predominante, se destacan los ganados, particularmente mulas, con el $46,34 \%$. Les siguieron las garantías inmuebles, con el $36,58 \%$ y, por último, los esclavos con el $17,08 \%$. El relevamiento de contratos crediticios notariales en los cuales se hipotecan bienes materiales contrasta también con aquellos estudios que señalaron la inexistencia casi generalizada de hipotecas de bienes raíces "salvo en que el deudor resultara insuficientemente fiable o sólido" (Mata, 1996, p. 154). Los protocolos relevados demuestran que, en ocasiones, incluso quienes detentaron una activa - y reconocida- actividad política y mercantil en la comarca respaldaron sus deudas notariales con garantías materiales. Por ejemplo, el 16 de mayo de 1760, Juan Joseph Arias Velázquez, vecino y capitán de Salta, tomó un préstamo por \$ 786 a favor de Agustina Araoz, que se reconoció, vecina y viuda de la plaza salteña, que habían resultado de una liquidación de cuentas previas. Ante Miguel Ruíz de Llanos, escribano público y de número y testigos, Miguel de Iramain, Thomas de Salina, Miguel Vicente Sola, el deudor manifestaba que 
(...) y para mayor seguro y cumplimiento de dicha paga en la forma que se expresa pongo y situo por especial hipoteca la parte de viña que poseo en el valle de Calchaquí, y me pertenece por derecho hereditario, de legitima paterna y la que heredare o pudiese heredar en caso que mi madre Doña Simona López fallezca $(. . .)^{12}$.

Dentro del porcentaje de escrituras avaladas con una garantía material, la hipoteca inmobiliaria tuvo preponderancia y fue empleada por deudores de reconocida actividad política y mercantil. En este tipo de hipotecas se dividen dos categorías: propiedades urbanas, constituidas comúnmente por casas y/o tiendas edificadas en la ciudad o sus alrededores más próximos que solían ser de posesión propia o herencia del deudor. Como fue el caso de los hermanos Valentín e Ignacio Salguero, quienes al ofrecer una garantía material que respaldara su deuda de $\$ 1.000$ contraída con Lorenza de la Cámara manifestaron:

(...) para mayor ajuntamiento sin perjuicio de dicha general ipoteca ponemos y señalamos por especial las casas que hemos heredado en la traza de esta ciudad de nuestros padres Don Zecilio Salguero y Doña Polonia Fernández que se componen de cuatro tiendas con sus trastiendas y de más edificado en ellas que lindan por la parte del oriente con casa de Don Joseph de Saravia y Aguirre, por el poniente con casas del Maestre de campo Don Joseph Burela y herederos de Don Lorenzo Castellanos, por el norte con calle Real de por medio con casas de Don Juan Vidart y por el sur con la huerta de dichos herederos Castellanos libres de censos dichas casas $(\ldots)^{13}$.

En segundo lugar, las propiedades rurales habitualmente se empleaban cuando la deuda superaba los 1.000 pesos. Las mismas incluían no sólo la edificación de la estancia, sino además ganados y bienes que poseía ésta en sus alrededores. Por ejemplo, nuevamente, Juan Joseph Arias, el 23 de julio de 1760, al formalizar una deuda contraída con Lorenza de la Cámara

\footnotetext{
${ }^{12}$ AHS, Sección notariales, protocolo 122, caja 10, Fs. 131 r. Juan Joseph Arias Velázquez nació en Salta en 1733, fue el primer hijo del matrimonio entre, Joseph Arias Velázquez y Elizondo y Simona López. Su hermano menor nació en 1735, de nombre Francisco Arias Velázquez. Provenían de una familia que se auto percibía herederos de los primeros conquistadores de la región, ocupó reiteradamente cargos en el ayuntamiento local y fue nombrado capitán de Salta. Se casó el 13 de septiembre de 1752, en la iglesia San Juan Bautista, de la plaza salteña, con María Josefa de la Corte Palacios. Juan Joseph Arias, 1752. Recuperado de https://familysearch.org/ark:/61903/1:1:W8BP-6CZM: 9 April 2020.

${ }^{13} \mathrm{AHS}$, Sección notariales, protocolo 136, caja 12, Fs. 54 r.
}

RHAA v. 56 n.1, 2021. ISSN: 0556-5960, ISSNe 2314-1549. CC BY-NC-SA 4.0 
por 1.000 pesos, hipotecaba "para mayor seguridad del pago de este debito pongo y afianzo por especial hipoteca la chacra y molino corriente que herede de mi padre el sargento mayor Joseph Arias"14. El resto de las hipotecas se constituyó de diversos géneros. Desde las mismas mulas transportadas hacia los polos potosinos y/o los efectos de castillas que adquirían y financiaban con créditos, hasta esclavos. Éste fue el caso del deudor cordobés Pedro Antonio Sosa, quien el 12 de octubre de 1769, al respaldar la deuda contraída con el salteño Gregorio Villa por 321 pesos, hipotecaba sus "7 Esclavos propios suios que tiene con mas su casa de su morada en dicha ciudad de Córdova"15.

A pesar de hallarnos ante un universo de sujetos provenientes de otras plazas virreinales, es significativo el predominio de acreedores locales. Aunque su participación varió en relación a los prestamistas foráneos en las obligaciones de pago escrituradas localmente. En el primer período (17601767) los acreedores avecindados (quienes se reconocen en la escritura vecinos) en Salta prestaron más del $56,41 \%$ del valor otorgado a través de las obligaciones de pago tanto a tomadores locales como itinerantes. Mientras que los prestamistas foráneos (incluye quienes se reconocen residentes o vecinos en otras plazas) representaron el 43,58\%. La situación cambió durante 1769-1776 pero sin grandes variaciones. Asistimos a mayor presencia de prestamistas vecinos en Salta, probablemente como correlato del aumento demográfico y el afincamiento de nuevos actores, que representan el $58,77 \%$ mientras que los acreedores no afincados en la plaza local disminuyeron al $41,23 \%$ con relación al período anterior.

Si bien en las obligaciones de pago sólo unos pocos actores sin afincamiento en Salta declaraban su lugar de avecindamiento o la región y/o ciudad hacia la cual se dirigían, aquellas obligaciones en las que sí se conoce el lugar de radicación estable o el destino de su viaje del deudor constituye una fuente de valiosa información para reconstruir los destinos geográficos de los préstamos escriturados como obligaciones de pago ante los notarios de Salta. ${ }^{16}$ Como exhibimos en el cuadro $n^{\circ} 3$, la plaza mercantil que sobresale a lo largo de todo el período analizado es Córdoba, hacia donde se dirigió el $29,82 \%$ de los volúmenes total prestados; le siguió San

\footnotetext{
${ }^{14}$ AHS, Sección notariales, protocolo 122, caja 10, Fs. 182 r.

${ }^{15} \mathrm{AHS}$, Sección notariales, protocolo 133, caja 11, Fs. 19 v.

${ }^{16}$ Cincuenta y siete escrituras de obligación (15,53\% del total) declararon el lugar de origen del deudor.
}

RHAA v. 56 n.1, 2020. ISSN: 0556-5960, ISSNe 2314-1549. CC BY-NC-SA 4.0 
Salvador de Jujuy $(26,32 \%)$. En tercer y cuarto lugar, Catamarca $(10,53 \%)$ y Tucumán $(7,02 \%)$.

Cuadro $n^{\circ}$ 3: Obligaciones de pago. Direcciones geográficas Salta (1760-1776)

\begin{tabular}{lll}
\hline Destinos de los préstamos & $\begin{array}{l}\text { Cantidad de } \\
\text { obligaciones }\end{array}$ & $\begin{array}{l}\text { Porcentaje de } \\
\text { obligaciones }\end{array}$ \\
\hline Córdoba & 17 & 29,82 \\
Jujuy & 15 & 26,32 \\
Catamarca & 6 & 10,53 \\
Tucumán & 4 & 7,02 \\
Buenos Aires & 3 & 5,26 \\
Chichas & 2 & 3,51 \\
La Frontera & 2 & 3,51 \\
La Rioja & 2 & 3,51 \\
Santiago del Estero & 2 & 3,51 \\
La Paz & 1 & 1,75 \\
Potosí & 1 & 1,75 \\
Sinti & 1 & 1,75 \\
Tarija & 1 & 1,75 \\
\hline Totales & 57 & 100,00 \\
\hline
\end{tabular}

Fuente: Elaboración propia a partir de AHS, Sección notariales, protocolos número 122 a 145,147. Cajas 10-13. Nota metodológica: se tomaron en cuenta aquellas obligaciones en las cuales figura el lugar de avecindamiento del deudor.

Las direcciones geográficas de los préstamos formalizados ante los escribanos locales trazaron conexiones espaciales cambiantes a lo largo del período analizado. Acompañaron la tendencia general de reconfiguraciones en la vinculación comercial de Salta con otros espacios económicos regionales, virreinales y transoceánicos (Anachuri, 2019b).

Como advertimos en la figura no 1 , entre 1760 y 1767 el vínculo con las plazas altoperuanas es evidente, entre las cuales se destaca La Paz y Chichas; y hacia el Sur, Córdoba, lo que explicaría la evidente presencia de acreedores cordobeses como se analiza más adelante. Entre 1768 y 1776, los espacios económicos hacia las cuales se dirigieron los préstamos 
formalizados en Salta se incrementaron. Es notoria la mayor orientación hacia plazas ubicadas el sur, principalmente, Buenos Aires, Córdoba y Santa Fe. A pesar de no perder importancia el eje altoperuano, los destinos geográficos de los préstamos notarialmente escriturados en Salta se diversificaron, incluso, es posible advertir nuevos destinos del crédito como correlato del proceso de mercantilización del espacio (La Rioja, Santiago del Estero, Tucumán).

Figura $\mathbf{n}^{\circ}$ 1: Direcciones geográficas de los préstamos notariales (1760-1767 y 1768-1776)
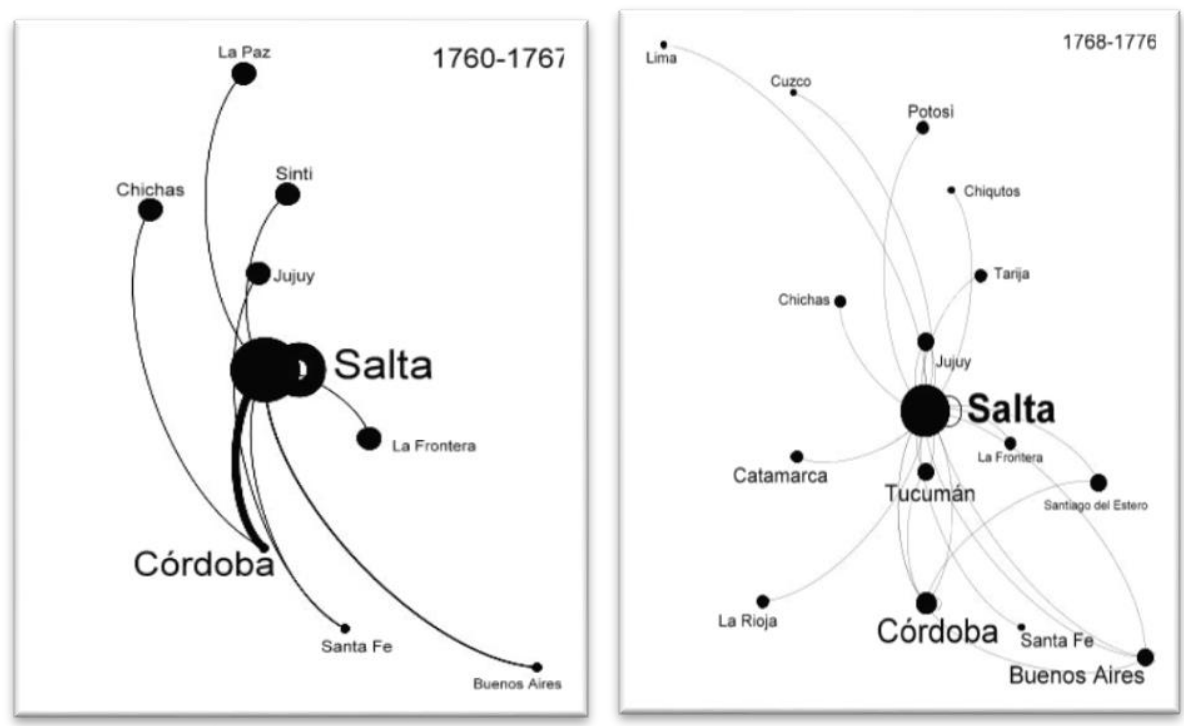

Fuente: Elaboración propia con Gephi 0.9 .2 a partir de AHS, Sección Notariales, Fuente: AHS, Protocolos 122-145,147. Cajas 10-13. Nota técnica: El tamaño de cada nodo está determinado por el nivel de interacciones que estructura el número de obligaciones de pago que tienen a ese centro urbano como destino del crédito. El grosor en los nombres de los centros urbanos figurantes, representa la constancia del vínculo. Para una aproximación véase Wasserman, 2018a.

Al vincularse directamente la actividad crediticia a los rubros comerciales y productivos, los movimientos atravesados en los volúmenes prestados y el número de escrituraciones anuales, no solo quedaron sujetas a los cambiantes ciclos del comercio mular y los intercambios altoperuanos, sino que respondieron a la conjugación de un abanico de espacios económicos 
hacia los cuales se orientó la circulación mercantil de Salta y a las circunstancias sociopolíticas del período. De hecho, es apreciable la sensibilidad que guardaron tanto en el volumen anual de los montos transferidos como la cantidad de escrituras formalizadas, ante las coyunturas políticas, sociales, civiles e institucionales. Sus fluctuaciones respondieron a la interacción entre el escenario local, regional-sur andino y transoceánico sobre los cuales desplegaron sus negocios habitantes avecindados definitivamente o residentes en tránsito hacia otros centros regionales (ver gráfico oㅜ 5). Desde mediados de 1760, tras superar los años de mayor conflictividad en la frontera oriental, la cantidad de escrituración y el volumen de los montos acreditados a través de las obligaciones contractuales de crédito iniciaron una tendencia creciente. El año de 1765 parece marcar un punto de inflexión con los años anteriores, incrementándose el promedio de los volúmenes acreditados hasta un $681 \%$ respecto a 1764. Desde entonces, con algunos altibajos, mantuvo ese desempeño hasta los levantamientos altoperuanos encabezados por Túpac Amaru II (Wasserman y Anachuri, 2020).

Gráfico $\mathrm{n}^{\circ}$ 5: Valores transferidos y número de obligaciones contractuales por año, Salta 1760-1776

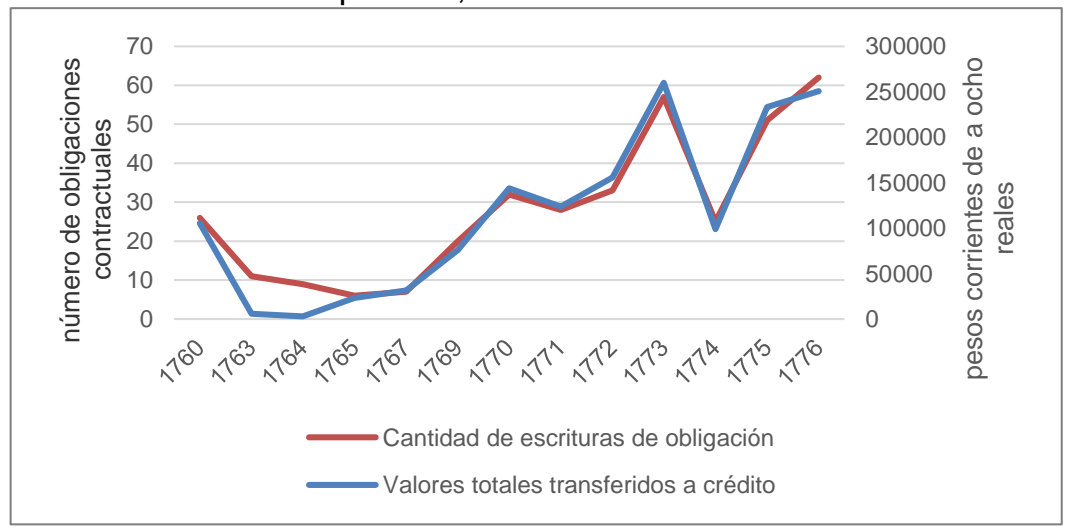

Fuente: Elaboración propia a partir de AHS, Sección notariales, protocolos número 122-145,147, Cajas 10-13. 


\section{El universo de actores en la práctica crediticia notarial de Salta}

El universo de actores involucrados, bajo diferentes roles, en la práctica crediticia notarial del período se integró por 353 personas. Fue un grupo reducido que constituyó el $8,82 \%$ sobre el conjunto de los habitantes urbanos de la comarca. Las 367 cartas de obligación relevadas corroboran estas conjeturas. Prácticamente en la mayoría de las escrituras, los actores involucrados, emplearon el apelativo del don/doña, un título honorífico invocado en la época de manera invariable cuando los miembros de la élite se topaban unos con otros o se presentaban en diferentes contratos y escrituras (Twinam, 2009, p. 21). Fueron miembros de corporaciones vinculadas al comercio, profesiones liberales, ocupaciones políticas, sectores clericales y castrenses.

En aquellas obligaciones en las cuales los actores registraron su ocupación y/o oficio ( $26,15 \%$ de los deudores y $37,32 \%$ de acreedores) predominan quienes se identifican "mercader tratante, del comercio y/o comerciante tratante". El $65,60 \%$ de los deudores se vincularon a las actividades comerciales. Mientras que, el $64,23 \%$ de acreedores manifestó dedicarse a la práctica mercantil. Lo manifestado en los papeles notariales demuestra el predominio de los miembros del sector mercantil, orientados al comercio exterior en desmedro de la plaza local ${ }^{17}$. Entre las demás ocupaciones declaradas por los contrayentes $u$ otorgantes de deudas notariales se destacaron miembros de sectores castrenses $(12,5 \%$ los deudores y $18,25 \%$ de los prestamistas). La presencia de coroneles, tenientes generales, brigadieres, sargentos en la práctica crediticia respondió a la militarización que atravesaron estos espacios desde la segunda mitad del siglo XVIII (Aramendi, 2020, pp. 459-460).

\footnotetext{
${ }^{17}$ Como sostiene Susan Socolow (1991) "mercader" y "comerciante" se empleaban como sinónimos para referirse a los comerciantes de larga distancia, y en general, se prefería la forma más antigua "mercader". Sin embargo, a mediados del siglo XVIII, se produjo una clara distinción entre la actividad económica y el status social descriptos por estos términos: el "comerciante" pasó a ser aquel individuo vinculado principalmente a los intercambios transoceánicos y de gran giro, por el contrario, el término "mercader" definió a quienes se dedicaron a la venta al menudeo y a los intercambios locales/regionales (p. 25). Los protocolos notariales salteños dejan de emplear el término mercader desde la década de 1770.
}

RHAA v. 56 n.1, 2020. ISSN: 0556-5960, ISSNe 2314-1549. CC BY-NC-SA 4.0 
El desembolso de los recursos crediticios notariales entre los miembros de la sociedad local estuvo circunscripto, por lo tanto, a aquel reducido grupo. Al considerar la distribución de los montos transferidos entre los actores que participaron en las obligaciones de pago, se evidencia en primer lugar que la oferta del capital por los deudores tendió a verse algo más concentrada que la distribución de ese capital entre los acreedores.

Gráfico n 6: Cartas de obligación. Distribución de los montos acreditados.

Salta 1760-1776

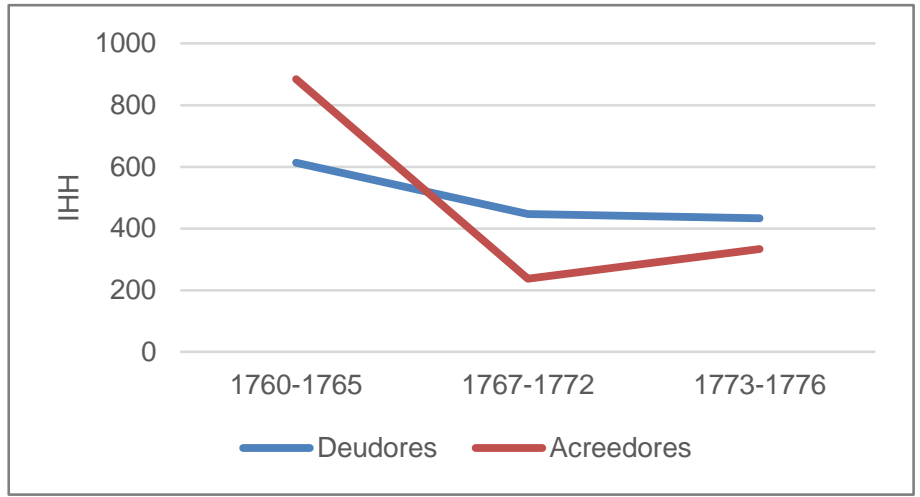

Fuente: Elaboración propia a partir de AHS, Sección notariales, protocolos número 122-145,147, Cajas 10-13.

Como puede apreciarse en el gráfico $n^{\circ}$ 6, la concentración de fondos ofrecidos por los acreedores a través de obligaciones de pago disminuyó entre 1767 y 1772 como probable resultado de la mercantilización del espacio y el incremento demográfico. Entre los períodos 1760-1765 y 17671772 se pasó de un coeficiente de Hirschman $(\mathrm{IHH})$ de 884 a uno de 237 para después mostrar una tendencia a la concentración durante 1773 y 1776 (con un Hirschman de 333) ${ }^{18}$. A su vez, la distribución del capital asignado entre quienes participaron como deudores también disminuyó.

${ }^{18}$ Calculamos el Herfindahl-Hirschman $(\mathrm{IHH})$ a partir de la siguiente fórmula:

$$
I H H=\sum_{i=1}^{N} s_{i}^{2}
$$


Aunque mostró mayor concentración que los prestamistas. Entre el período 1760-1765 y 1676-1772 se pasó de un coeficiente de Hirschman (IHH) de 613 a uno de 447 para después proseguir a la disminución en la concentración entre 1773 y 1776 (con un Hirschman de 433 más elevado que los acreedores).

Al poner la mirada hacia las escrituras de obligación observamos que se asistió a una mayor dispersión del crédito entre sus actores (véase gráfico $n^{\circ} 7$ ). Si bien la distribución de las escrituras se concentró más entre los deudores que entre los acreedores, los niveles globales de concentración fueron considerablemente más bajos que los apreciados en la distribución de fondos prestados. La concentración de escrituras de obligación ofrecidas por los acreedores disminuyó considerablemente entre 1767 y 1772. Entre los períodos 1760-1765 y 1767-1772 se pasó de un coeficiente de Hirschman $(\mathrm{IHH})$ de 448 a uno de 156 para después proseguir a la baja en la concentración en 1773 y 1776 (con un Hirschman de 122, el más bajo de todo el período). Por su parte, la distribución del capital asignado entre quienes participaron como deudores también disminuyó, aunque mostró mayor concentración que los prestamistas. Entre 1760-1765 y 1676-1772 se pasó de un coeficiente de Hirschman $(\mathrm{IHH})$ de 410 a uno de 272 para después proseguir a la disminución en la concentración entre 1773 y 1776 (con un Hirschman de 134).

Gráfico $\mathbf{n}^{\circ}$ 7: Cartas de obligación. Distribución de las obligaciones de pago (escrituras). Salta 1760-1776

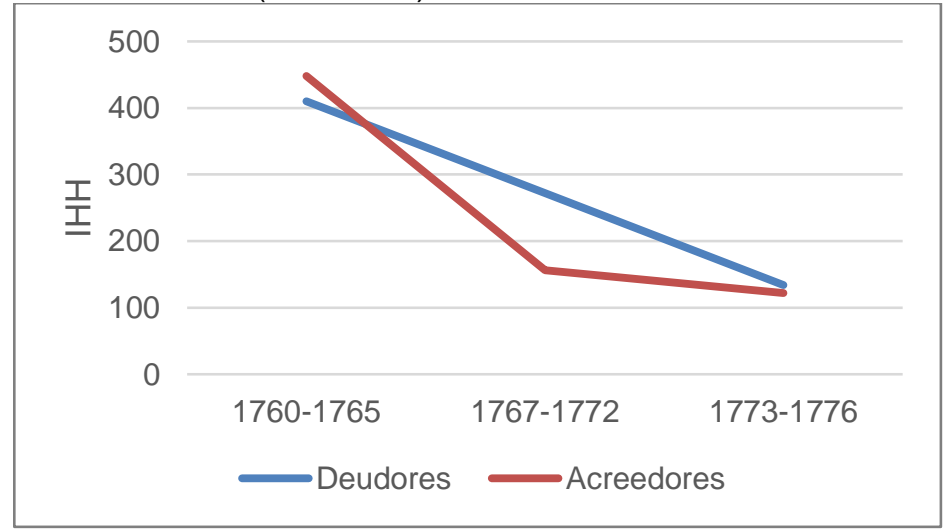

Fuente: Elaboración propia a partir de AHS, Sección notariales, protocolos número 122 a 145,147, Cajas 10-13. 
La existencia de redes menos densamente conectadas entre acreedores y deudores, en un contexto de riesgos, luchas facciosas y cambios políticos e institucionales, condujo a concentrar la transferencia de préstamos en los pocos tomadores de deudas, con capital relacional reconocibles e identificables, como Joseph de Alvarado, principal deudor de todo el período. Concentró el 13,14\% sobre el total de obligaciones de pago y tomó prestado en conjunto $\$ 110.785$.

Originario de Cantabria, junto a Manuel de Tezanos Pinto llegaron a América como otros montañeses que formaron parte de las migraciones en cadena de la segunda mitad del siglo XVIII. A pesar de proceder de la misma región de España, sus vidas se cruzaron en Potosí, donde habían arribado en pos de respectivos intereses sobre el comercio de las mulas y los efectos europeos. Se incluyeron en las redes de paisanaje en Potosí, desde donde organizaron sus familias y negocios (Conti y Gutiérrez, 2009). Las relaciones con actores de reconocida actividad política y mercantil de Potosí se evidencian en las primeras obligaciones de pago que registró Alvarado en Salta.

El 14 de abril de 1770 se presentó ante los escribanos locales en virtud de "residente, comerciante y próximo hacer viaje a las Provincias del Perú" como apoderado de Pedro de la Revilla, vecino de Potosí, comerciante y administrador general de correos, para comprar en Salta "hasta la cantidad de dos mil mulas". Ese día Joseph de Alvarado se obligó (en nombre de su apoderado) por \$7.611 a favor del cordobés Manuel Calderón procedidos de la venta de mulas $^{19}$. Luego de 1780 , y sin descuidar el rubro de mulas, sus negocios se diversificaron en torno a la compra y venta de "efectos varios" entre Buenos Aires, Potosí y Cuzco, siendo sus principales proveedores Joaquín Pinto (en Buenos Aires) y Domingo Manuel Sánchez de Bustamante (en Jujuy) uno de los principales comerciantes de la plaza jujeña (Conti y Gutiérrez, 2009, pp.146-147). El vínculo, con este último trascendió el mercantil, puesto que Joseph de Alvarado se casó el 19 de mayo de 1780 con Francisca Segunda Sánchez de Bustamante, hija de Domingo Manuel y María Tomasa González Araujo Ortiz de Zárate ${ }^{20}$.

\footnotetext{
${ }^{19} \mathrm{AHS}$, Sección notariales, protocolo 134, caja 12, Fs. 122 r.

${ }^{20} J$ osef Manuel Alvarado Bustamante, 1785. Recuperado de https://familysearch.org/ark:/61903/1:1:XNLK-JL9: 13 February 2020.
}

RHAA v. 56 n.1, 2021. ISSN: 0556-5960, ISSNe 2314-1549. CC BY-NC-SA 4.0 
Similar a otras ciudades hispanoamericanas, los deudores que mayor cantidad de operaciones otorgaron ante el escribano no mostraron tendencia acudir frecuentemente al mismo acreedor (Wasserman, 2018b, pp. 220-223). Es así como Joseph de Alvarado, el deudor más frecuente, realizó el 16,66\% (2 de 12 operaciones crediticias) ante el mismo acreedor: Antonio de Figueroa ${ }^{21}$. Ratificamos, así, que los principales deudores no retornaban repetidamente al mismo prestamista, tal como se esperaría que hicieran si procuraban ganar la confianza de acreedores, cada nueva operación crediticia, solía implicar una nueva contraparte (Wasserman, 2018b, p. 221). La escasa frecuencia de los deudores por acudir a un mismo acreedor corrobora que los acreedores tampoco restringieron sus préstamos a un pequeño grupo de prestatarios, que se demostraran necesariamente confiables, en función de las garantías materiales y relacionales.

Estas características del crédito notarial en Salta dieron paso a redes de muy baja densidad general (véase cuadro $n^{\circ} .4$ ). Partimos de redes crediticias estructuradas por actores que configuran nodos y operaciones crediticias que forman aristas (las cuales a la vez están definidas por cada compromiso crediticio registrado en obligación de pago). Ello conformó retículas con vínculos cuyas direcciones prosiguieron el sentido de las obligaciones de pago. Los actores operaban sólo en redes segmentadas que configuraron subredes altamente conectadas al interior de la misma, pero escasamente vinculadas con el resto de los miembros de la red. Estas subredes existían en relativo aislamiento entre sí. En efecto, hubo redes simultáneas que no estaban en absoluto, 0 sólo ligeramente, interconectadas entre sí. La mayoría de las obligaciones de pago participaba de múltiples vínculos, dando lugar a una red dispersa y descentralizada. La modularidad se mantuvo relativamente con niveles altos, lo que dio paso a una multitud de pequeñas y medianas comunidades de deudores, nucleadas en torno a los principales acreedores. Dichos grupos estuvieron muy densamente conectados entre ellos y escasamente conectados con el resto de actores participantes de la red. El análisis de las redes de obligaciones de pago en Salta, presenta, similitudes, a la dinámica

\footnotetext{
${ }^{21}$ Fueron en dos oportunidades. La primera vez lo hizo el 29 de marzo de 1773 por la cuantiosa suma de $\$ 10.038$ procedidos de la venta de mulas. La segunda, el 25 de marzo de 1776, volvió a formalizar una obligación por \$ 8.359 procedidos de tropas de mulas. AHS, Sección notariales, protocolo 138, caja 13, Fs. 80 r. AHS, Sección notariales, protocolo 144, caja 14, Fs. 87 v.
}

RHAA v. 56 n.1, 2020. ISSN: 0556-5960, ISSNe 2314-1549. CC BY-NC-SA 4.0 
de las redes crediticias en la Buenos Aires del siglo XVII (Wasserman, 2018b, pp. 221-223).

Cuadro $n^{\circ}$ 4: Variables estructurales de las redes entre acreedores y deudores por período. Salta 1760-1776

\begin{tabular}{cccccc}
\hline Período & Nodos / Actores & Aristas & Densidad & Modularidad & Módulos \\
\hline $1760-1765$ & 27 & 40 & 0,046 & 0,554 & 7 \\
$1767-1772$ & 96 & 90 & 0,022 & 0,584 & 8 \\
$1773-1776$ & 230 & 237 & 0,014 & 0,523 & 11 \\
\hline
\end{tabular}

Fuente: Elaboración propia a partir de AHS, Sección notariales, protocolos número 122 a 145,147, Cajas 10-13. Nota técnica: a) Los nodos modelan actores participantes en calidad de prestamistas y/o deudores b) las aristas modelan compromisos crediticios formalizados en obligación de pago escriturados entre los nodos c) el valor de esta medida puede oscilar entre 0 y 1 : alcanzando este último valor, la red, estaría completamente interconectada entre sus nodos d) La modularidad es una medida de la estructura de las redes, diseñada para medir la fuerza de la división de una red en módulos (también llamados grupos, grupos o comunidades). Las redes con alta modularidad tienen conexiones densas entre los nodos dentro de los módulos, pero escasas conexiones entre los nodos en diferentes módulos. La modularidad se utiliza a menudo en métodos de optimización para la detección de estructura de la comunidad en las redes (Kuz, Falco y Giandini, 2016, p. 94; Wasserman, 2018a; 2020).

Entre 1760 y 1765, la cantidad de actores involucrados en dicha red crediticia fue de 27 (nodos), quienes concertaron en total 40 transacciones escrituradas en obligación de pago (aristas). Como observamos en la figura no 2, los nodos de mayor dimensión, clasificados numéricamente, representan las personas que realizaron mayores cantidades de préstamos notariales. Entre quienes se destacan Estanislao Quinteros (cód.11); Andrés Delgado (cód. 5); Francisco Antonio González y San Millán (cód. 12) y Antonio Figueroa (cód. 7), reconocidos por su actividad política y mercantil en la comarca. Si realizamos un recorte sobre los actores que reunieron el $50 \%$ del capital movilizado durante el decenio (esto es el grupo de personas con mayor participación económica sobre el total de transacciones crediticia en calidad de acreedor) la nómina se circunscribe a estos cuatro actores (véase cuadro $\mathrm{n}^{\circ}$ 5). 
Figura $\mathbf{n}^{\circ}$ 2: Red de obligaciones de pago escrituradas en Salta 1760-1765

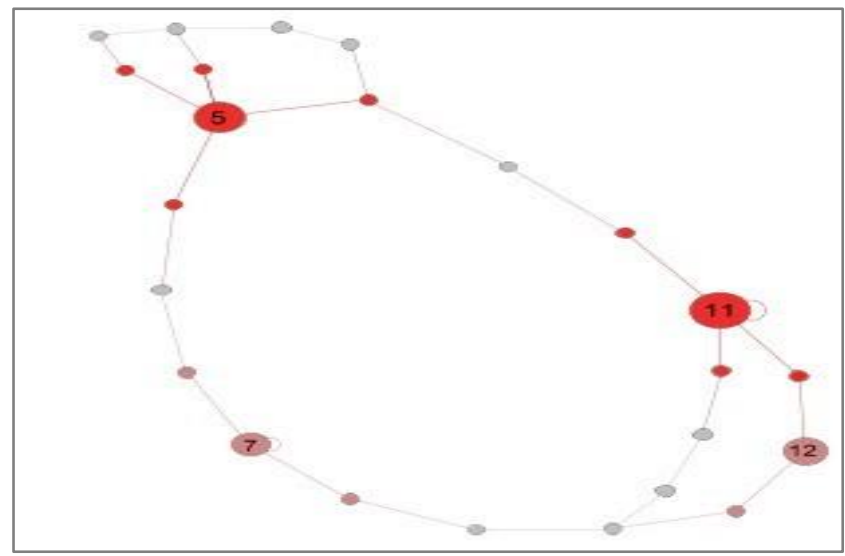

Fuente: Elaboración propia a partir de AHS, Sección notariales, protocolos número 122 a 145,147, Cajas 10-13. Nota técnica: El tamaño de cada nodo está definido por su grado de entrada que representa la cantidad de obligaciones de pago a su favor registrada durante el decenio graficado y representa la frecuencia del prestamista, o su presencia en ese universo contractual de compromisos crediticios.

Cuadro $\mathbf{n}^{\circ}$ 5: Actores que concentran el $50 \%$ del monto total movilizado en la red de obligaciones de pago. Salta 1760-1765

\begin{tabular}{lcc}
\hline \multicolumn{1}{c}{ Actor } & Participación & \% Participación \\
\hline Estanislao Quinteros & $\$ 26.562$ & 20,62 \\
Andrés Delgado & $\$ 15.875$ & 12,33 \\
Francisco Antonio & $\$ 11.891$ & \\
González y San Millán & $\$ 9.086$ & 9,23 \\
Antonio Figueroa & 7,05 \\
\hline
\end{tabular}

Fuente: Elaboración propia a partir de AHS, Sección notariales, protocolos número 122 a 145,147 , Cajas 10-13.

Desde 1770 nuevos actores se incorporaron a la comunidad salteña, y en muchos casos, se posicionaron como destacados prestamistas. El arribo de nuevos contingentes a la plaza demuestra la movilidad de la población y las oportunidades que ofreció Salta para quienes migraban hacia América (Anachuri, 2019a; 2019b; 2019c; Justiniano, Madregal y Anachuri, 2019). Tanto la afluencia de nuevos sujetos como las luchas facciosas al interior de la oligarquía, tuvieron su correlato en la reconfiguración del universo de 
actores del crédito notarial. Por ejemplo, los conflictos ocasionados por la expulsión de la Compañía de Jesús desplazaron de su posición como uno de los principales acreedores (1760-65) a Andrés Delgado, director del colegio de los jesuitas en Salta. Por el contrario, otros, como Antonio Figueroa, mantuvieron sus posiciones en los años subsiguientes.

Antonio Figueroa nació en Córdoba y comenzó a operar en Salta tempranamente, desde 1760 aún como residente y apoderado de importantes ganaderos cordobeses en la plaza norteña. Su afincamiento definitivo en Salta provino tras su primer matrimonio, con María del Carmen Toledo Pimentel, miembro de una familia estrechamente relacionada con los jesuitas, lo que posibilitó a Figueroa la obtención de créditos de la Compañía. Logró, sin embargo, no malquistarse con los vecinos que celebraron la expulsión, continuando su ascendente carrera social. En 1778 se hizo propietario de la estancia el bañado, una de las más importantes, pertenecientes a los Jesuitas. Ocupó repetidas veces el cargo de alcalde en el Cabildo, y ese mismo sería nombrado Justicia Mayor de la ciudad de Salta. En el año 1780 ostentaba los cargos de coronel de milicias, teniente de gobernador, Justicia Mayor, presidente de la Junta Municipal de Temporalidades y síndico ecónomo del Convento de San Francisco y en 1784 volvería a desempeñarse como Alcalde de Primer Voto en el Cabildo (Mata, 1991). Para 1767-1772 apreciamos todavía los efectos de las luchas facciosas y la fuerte presencia de comerciantes cordobeses en el círculo crediticio salteño. A la vez, se hace más visible la presencia de "nuevos" actores peninsulares.

Entre esos años, la cantidad de actores involucrados en dicha red crediticia fue de 96 (nodos) quienes concertaron en total 90 transacciones escrituradas en obligación de pago (aristas). Entre los principales acreedores del período, identificados en la siguiente figura numéricamente, se destacan: Thomás Allende (cód. 62); Antonio Figueroa (cód. 2); Pedro de Elexalde (cód. 59) y Gregorio Nicolás Arrascaeta (cód. 21) (véase figura $n^{\circ}$. $3)$. Si realizamos un recorte sobre los actores que reunieron el $50 \%$ del capital movilizado durante esos años, el nivel relativamente bajo en la concentración de los fondos acreditados (véase gráfico no 7 ) tuvo como correlato una nómina circunscripta a 18 sujetos, encabezados por aquellos (véase cuadro no 6). 
Figura $\mathbf{n}^{\circ}$ 3: Red de obligaciones de pago escrituradas en Salta 1767-1772

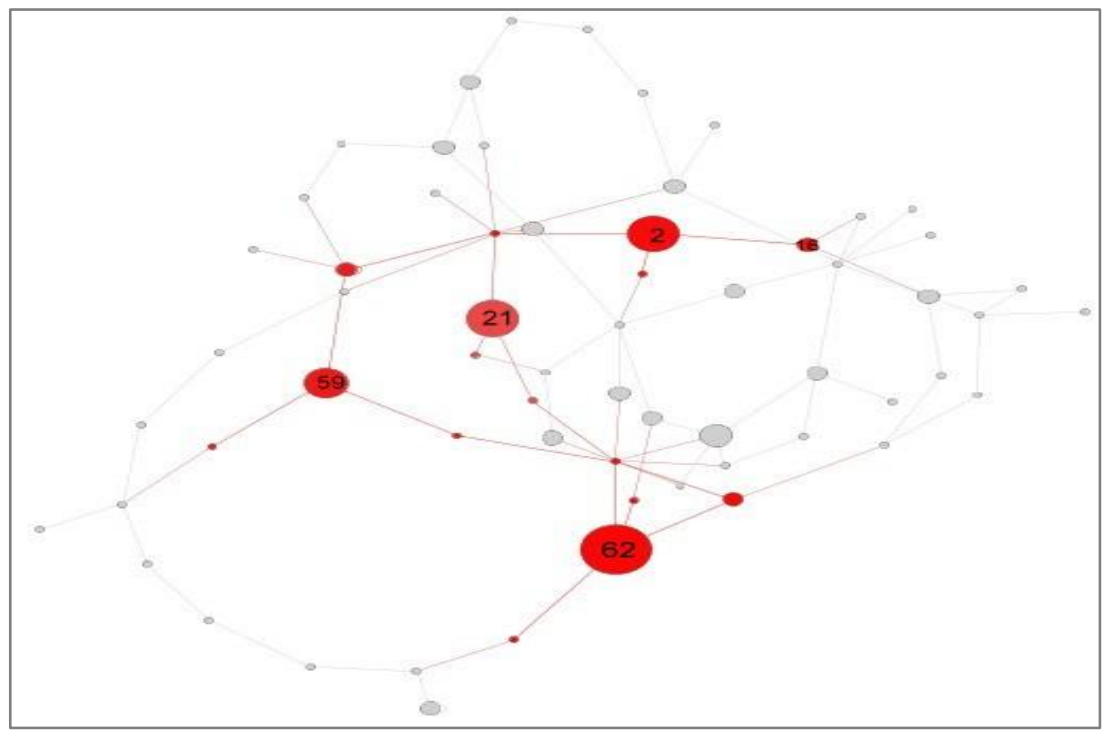

Fuente: Elaboración propia a partir de AHS, Sección notariales, protocolos número 122 a 145,147, Cajas 10-13. 
Cuadro $n^{\circ}$ 6: Actores que concentran el $50 \%$ del monto total movilizado en la red de obligaciones de pago. Salta 1767-1772

\begin{tabular}{lcc}
\hline \multicolumn{1}{c}{ Actor } & Participación & \% Participación \\
\hline Thomas Allende & $\$ 44.257$ & 8,33 \\
Antonio Figueroa & $\$ 22.765$ & 4,29 \\
Pedro Elexalde & $\$ 19.645$ & 3,70 \\
Gregorio de Arrascana & $\$ 18.044$ & 3,40 \\
Antonio de la Quintana & $\$ 17.758$ & 3,34 \\
Pedro Reguard & $\$ 14.909$ & 2,81 \\
Miguel Vicente Solá & $\$ 14.351$ & 2,70 \\
Pablo Xigera & $\$ 13.684$ & 2,58 \\
Manuel Francisco de la Vega & $\$ 12.143$ & 2,29 \\
Velarde & $\$ 11.921$ & 2,24 \\
Joseph Endeiza & $\$ 11.487$ & 2,16 \\
Gabriel Torres & $\$ 11.376$ & 2,14 \\
Miguel Antonio Fernández & $\$ 10.707$ & 2,02 \\
Francisco Antonio Diaz & $\$ 10.647$ & 2,00 \\
María Mauricia de Allende & $\$ 10.212$ & 1,92 \\
Fermín de la Sierra Pico & $\$ 9.899$ & 1,86 \\
Juan Vázquez Maurin & $\$ 9.679$ & 1,82 \\
Cayetano Viniegra & $\$ 9.368$ & 1,76 \\
Joseph Laigorri & & .
\end{tabular}

Fuente: Elaboración propia a partir de AHS, Sección notariales, protocolos número 122 a 145,147, Cajas 10-13.

Entre 1773 y 1776 , el aumento demográfico y la mercantilización del espacio tuvieron como correlato el incremento de acreedores y/o deudores y la intensificación del crédito. Asistimos a una red crediticia formada por 230 individuos (nodos) que formalizaron un total 237 obligaciones de pago (aristas). Entre los principales actores otorgantes de préstamos se destacan: Miguel Vicente Solá (cód. 102); Antonio Figueroa (cód. 4) y Juan Francisco Leanir (cód. 72) (figura ํㅜ 4). 
Figura $\mathbf{n}^{\circ}$ 4: Red de obligaciones de pago escrituradas en Salta 1773-1776

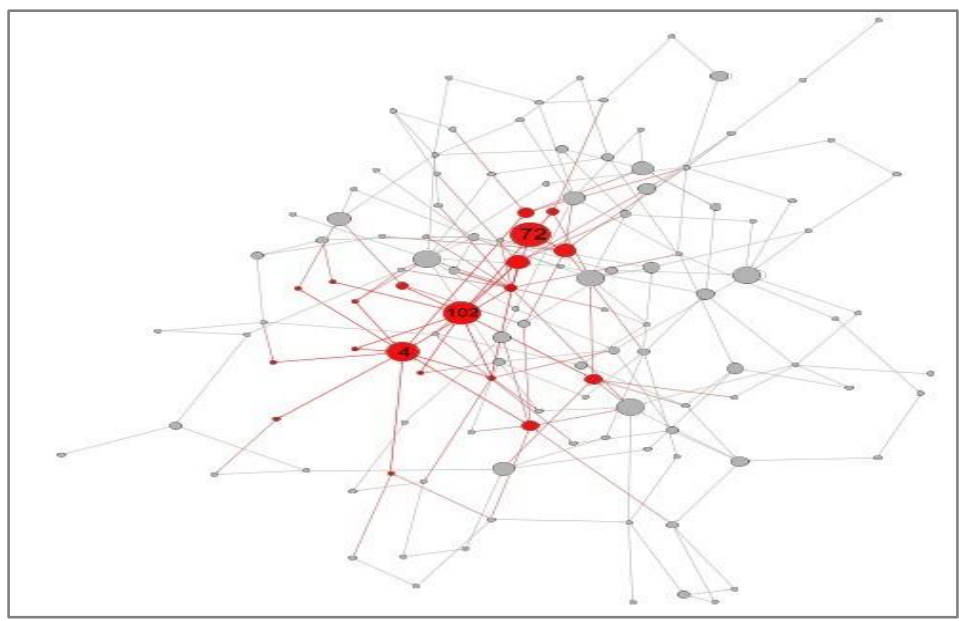

Fuente: Elaboración propia a partir de AHS, Sección notariales, protocolos número 122-145,147, Cajas 10-13.

Miguel Vicente Solá, proveniente de Cataluña y avecindado definitivamente en Salta, hacia 1780 tras contraer nupcias con María Felipa Martínez de Tineo y Castellanos. El enlace lo convirtió en vecino encomendero, pues María Felipa poseía la única encomienda del Valle de Lerma a fines del siglo XVIII, y le permitió ostentar junto a su cuñado, el coronel José Francisco Martínez de Tineo, el grado de Teniente Coronel del Regimiento de Dragones de la ciudad de Salta (Mata, 1991, pp. 72-73). Los préstamos formalizados ante los escribanos locales, provinieron, en su mayoría, de su actividad en el comercio mular. Los mismos se destacaron por el voluminoso monto para la época. Por ejemplo, en 1776 registró el crédito de mayor volumen de todo el período. Se formalizó el 18 de marzo de 1776, Manuel Antonio Concha se obligó por la cuantiosa suma de \$ 45.345 a favor de Miguel Vicente Solá, procedidos, de dos tropas de mulas. ${ }^{22}$ Hacia 1770 era significativa la presencia de peninsulares, que arribaron años anteriores, como acreedores notorios en el círculo crediticio (cuadro $n^{\circ} 7$ ).

${ }^{22} \mathrm{El}$ deudor se comprometió rescindir la deuda en el término de doce meses. Finalmente, se canceló por su apoderado, Cayetano Viniegra, el 16 de marzo de 1780. AHS, Sección notariales, protocolo 144, caja 14, Fs. 71 v. 
Cuadro $\mathrm{n}^{\circ} 7$ : Actores que concentran el $50 \%$ del monto total movilizado en la red de obligaciones de pago. Salta 1773-1776

\begin{tabular}{lcc}
\hline \multicolumn{1}{c}{ Actor } & Participación & \% Participación \\
\hline Miguel Vicente Solá & 86225 & 10,23 \\
Antonio Figueroa & 67635 & 8,02 \\
Juan Francisco Leanir & 61842 & 7,34 \\
Cayetano Viniegra & 31541 & 3,74 \\
Isidoro Abarria & 25426 & 3,02 \\
Joseph de Allende & 24904 & 2,95 \\
Francisco Antonio González y San Millán & 21906 & 2,60 \\
Joseph Xavier de Amenábar & 21350 & 2,53 \\
Thomas Rodríguez & 21159 & 2,51 \\
Francisco Joseph Diaz & 20850 & 2,47 \\
Juan Antonio Lezica & 20509 & 2,43 \\
Antonio Pardo & 17606 & 2,09 \\
Manuel Antonio Tejada & 16718 & 1,98 \\
\hline
\end{tabular}

Fuente: Elaboración propia a partir de AHS, Sección notariales, protocolos número 122 a 145,147, Cajas 10-13.

Otro caso lo representó Cayetano Viniegra, originario de Galicia. Una vez en Salta, contrajo matrimonio con Ángela Isasmendi, hija del matrimonio entre Domingo de Isasmendi Ormazabal y Josefa Gertrudis de Echalar y Morales. El padre de la flamante esposa fue encomendero y propietario de la hacienda de Molinos en el Valle Calchaquí, una de las más importantes y extensas de la región, encargado del correo real, miembro de la Junta de Temporalidades luego de la expulsión de los jesuitas, alcalde de Segundo Voto en el Cabildo de Salta en 1768. Su cuñado, Nicolás Severo de Isasmendi, iba a ser el último gobernador intendente de la Intendencia de Salta del Tucumán ${ }^{23}$. Entroncado a una de las principales familias de la época, Cayetano Viniegra participó como apoderado de criadores de mulas de Santa Fe, Buenos Aires, Córdoba, Potosí y Lima. A inicios de la década

23"Argentina, Salta, registros parroquiales, 1634-1972. Cayetano Viniegra in entry for Angela Isasmendi, 1821. Recuperado de https://familysearch.org/ark:/61903/1:1:WT31-79ZM: 9 April 2020. 
de 1770 figura en los protocolos notariales con el cargo de maestre de campo ${ }^{24}$. Su actividad crediticia es un claro ejemplo de la alteridad con la cual operaron estos actores.

A lo largo del periodo analizado fueron siete los préstamos que solicitó. Cinco fueron para costear sus propias actividades comerciales. Por ejemplo, el 21 de mayo de 1769 formalizó una deuda de $\$ 7.440$ a favor de Fermín de la Sierra Pico procedidos de "los efectos de Castilla que el dicho me ha vendido y que tengo recibidos antes el otorgamiento de esta escritura"25. Mientras que en dos ocasiones formalizó deudas en situación de apoderado de otros comerciantes en la plaza salteña. Como la obligación realizada el 25 de junio de 1771 en la cual se reconoció deudor "por el poder de Eugenio Lerdo de Tejada y Don Bernardo Sánchez Larrea vecino de Buenos Aires" dos reconocidos comerciantes y políticos del universo mercantil porteño, por \$1.393 a favor del comerciante salteño Pedro Manuel López, que resultaron de una serie de cuentas que mantuvieron ${ }^{26}$. Las operaciones crediticias de Viniegra, tanto en calidad de acreedor y deudor, invitan revisar aseveraciones en las cuales se lo identificó solamente como acreedor y vinculado exclusivamente al comercio mular. Él mismo solicitó préstamo para solventar la adquisición de géneros de castilla para su estipendio en Salta ${ }^{27}$.

${ }^{24} \mathrm{El}$ acceso a documentación inédita devela que Cayetano Viniegra mantuvo sólidos vínculos con su Galicia natal. Prueba de ello es que José Arechavaleta, capitán y vecino de La Coruña y apoderado de Viniegra a quien reconoce como "residente en la ciudad de Salta, Provincia de Tucumán, en los reinos de Yndias" lo representó en un pleito con Pedro de Herce y Teijeiro, vecino de La Coruña, sobre la misión de posesión de una serie de propiedades y otros bienes. Archivo de la Real Cancillería de Valladolid, Registro de la ejecutoría, Caja 3380, Fs. 33.

${ }^{25}$ AHS, Sección notariales, protocolo 130, caja 11, Fs. 26 r.

${ }^{26} \mathrm{AHS}$, Sección notariales, protocolo 135, caja 12, Fs. 195 r. La primera deuda que formalizó en Salta en nombre de otro actor la registró el 10 de abril de 1770 en nombre de Manuel Praga, comerciante en Potosí. Fue de \$3.081 en favor del salteño Pedro Díaz Chávez, procedentes de una venta de mulas. AHS, Sección notariales, protocolo 134, caja 12, Fs. $121 \mathrm{v}$.

27 Mata (1994) al momento de referirse a la actuación de Viniegra en el círculo crediticio sostuvo que en "el crédito comercial Viniegra solo aparece involucrado en calidad de acreedor y siempre en relación con el comercio mular. Así reconocen deberle dinero en efectivo 0 por venta de mulas 0 habilitación de tropas comerciantes procedentes del Perú, Potosí o Córdoba. Sin embargo, esta condición

RHAA v. 56 n.1, 2020. ISSN: 0556-5960, ISSNe 2314-1549. CC BY-NC-SA 4.0 


\section{A modo de cierre}

El relevamiento y análisis de fuentes notariales inéditas, junto, a la elaboración de series, el Análisis de Redes Sociales y la reflexión historiográfica permitieron revelar las características, relevancia e incidencia del crédito en Salta, durante los últimos años, de la Gobernación del Tucumán.

Dimos a conocer que, al igual que otras ciudades hispanoamericanas, el préstamo notarial y sus respectivas obligaciones contractuales, contribuyeron a la dinámica económica de Salta y a su posicionamiento en nodo comercial y financiero de la región del Tucumán virreinal. Otorgó los engranajes financieros fundamentales para movilizar las producciones rurales y los productos del comercio regional y transoceánico sobre los cuales orientaron sus negocios actores afincados definitivamente como vecino o en tránsito hacia otros centros sudamericanos.

El movilizado contexto político e institucional de esos años influyó en las dinámicas estructurales y relacionales de la operatoria crediticia. Gran parte de la década de 1760 (período en cual se asistió a permanentes campañas ofensivas sobre el Chaco y la expulsión de la Compañía de Jesús) los volúmenes acreditados y la cantidad de escrituras crediticias formalizada, fueron relativamente bajas en relación al período subsiguiente. Una vez superada la conflictividad, alcanzada una relativa estabilidad social y una revitalización de los intercambios comerciales regionales y transoceánico, ante el evidente ascenso de Buenos Aires, el año 1770 significó un momento de inflexión. Salta, empezó a vincularse hacia nuevos espacios económicos y a posicionarse en un nodo comercial y financiero, como lo prueban las direcciones geográficas de los préstamos notarialmente escriturados en la plaza local y la mayor presencia de actores avecindados en otras plazas virreinales.

A medida que la actividad crediticia se revitalizó, nuevos actores se posicionaron como importantes acreedores. Esto como causa de los conflictos intra oligárquico, pero también - y tal vez como principal causadel arribo de nuevos contingentes, que desplazó algunos y consolidó la presencia de nuevos actores. Muchos de los principales acreedores de

de acreedor es probablemente resultado de su carácter de apoderado. En ningún caso es deudor lo cual afirma su condición de intermediario" (p. 194).

RHAA v. 56 n.1, 2021. ISSN: 0556-5960, ISSNe 2314-1549. CC BY-NC-SA 4.0 
1770 en adelante fueron emigrantes peninsulares, que hallaron en las actividades económicas propias de la esfera de la circulación, como el préstamo, un rubro económicamente más rentable que la producción rural. Algunos como Manuel Antonio Tejada, Francisco González y San Millán, Pedro de Elexalde o Cayetano Viniegra, iniciaron por esos tempranos años un vertiginoso ascenso mercantil que los llevaría a erigirse, años más tarde, en las personas más rica de la región, producto de su actividad como prestamistas. Ello obliga a considerar otras alternativas de enriquecimiento, en el período, provenientes de las actividades económicas propias de la esfera de la circulación, como el préstamo y el comercio, a fin de complejizar la vida económica y social de aquella comarca virreinal y, sobre los cuales, la historiografía local ahondó escasamente (Justiano y Tejerina, 2020).

Por último, el análisis del universo de acreedores y deudores que concertaron mayor número de obligaciones y volúmenes dinerarios prestados por período ratifica que el nivel de concentración en la actividad financiera en la comarca salteña se circunscribió a un reducido grupo. Quienes en su mayoría se identificaban en las escrituras de préstamos vinculados a la actividad comercial y los sectores castrense. Situación que, contribuyó, desde luego, a reproducir las desigualdades, característica inherente de estas economías y sociedades de Antiguo Régimen.

\section{Bibliografía}

Acevedo, E. (1965). La intendencia de Salta del Tucumán en el Virreinato del Río de la Plata. Universidad Nacional de Cuyo.

Anachuri, M. G. (2019a). Créditos y fortunas. El caso de Juan Antonio Moldes en la Salta de fines del siglo XVIII. América Latina en la Historia Económica, $26 \quad$ (3), $\quad$ pp. 1-25. https://doi.org/10.18232/alhe.972

Anachuri, M. G. (2019b). Entre riesgos, especulación e incertidumbre global. géneros, circulación y comerciantes ultramarinos en la Salta tardovirreinal. Revista de la Escuela de Historia, 18 (2), pp. 1-25. Recuperado de http://portalderevistas.unsa.edu.ar/ojs/index.php/reh/article/view/1372/ 0 
Anachuri, M. G. (2019c). Relevancia e incidencia del crédito en la circulación de un nodo virreinal: Salta, 1788-1809. Anuario Centro de Estudios Económicos de la Empresa y el Desarrollo, (11), pp. 17-59. Recuperado de https://ojs.econ.uba.ar/index.php/CEEED/article/view/1442

Aramendi, B. (2020). Gobierno y administración en el Tucumán, segunda mitad del siglo XVIII. En A. M. Guillermno Nieva Ocampo. La antigua gobernación del Tucumán: política, sociedad y cultura: S. XVI al XIX (pp. 435-483). Milor.

Barriera, D. (2002). Por el camino de la Historia Política: hacia una Historia Política configuracional. Secuencia. Revista de Historia y Ciencias Sociales , (53), pp. 163-196.

Barriera, D. y Tarragó, G. (2000). El vínculo y la posibilidad-práctica mercantil, construcción de vínculos sociales y factores de riesgo (Santa Fe, siglo XVIII). Primeras Jornadas de Historia Regional Comparada, (pp. 1-16). Porto Alegre.

Bertrand, M. y Moutoukias, Z. (2018). Introducción. Actores, instituciones, Estado: la fiscalidad y los debates historiográficos sobre el cambio político. En M. B. Moutoukias. Cambio institucional y fiscalidad. Mundo hispánico, 1760-1850 (pp. 1-24). Collection de la Casa de Velázquez.

Bonialian, M. y Hausberger, B. (2018). Consideraciones sobre el comercio y el papel de la plata hispanoamericana en la temprana globalización, siglos XVI-XIX. Historia de México, 68 (1), pp. 197-244. https://doi.org/10.24201/hm.v68il.3641

Camarda, M. (2015). La región Río de la Plata y el comercio ultramarino durante las últimas décadas del siglo XVIII. Universidad Nacional de La Plata .

Comadrán Ruiz, J. (1969). Evolución demográfica argentina durante el período hispano (1535-1810). Universitaria.

Conti, V. (2005). Articulaciones mercantiles del espacio saltojujeño durante el período rosista. Universidad Nacional de La Plata.

Conti, V. y Gutiérrez, M. (2009). Empresarios de los Andes de la colonia a la independencia. Dos estudios de casos de Jujuy. América Latina en la Historia Económica, (31), https://doi.org/10.18232/alhe.v16i2.419

pp.

138-163. 
Del Valle Pavón, G.; Ibarra, A. y Alcántara, A. (2017). Introducción. En G. D. Ibarra, Redes, coorporaciones comerciales y mercados hispanoamericanos en la economía global, siglos XVII-XIX (pp. 7-26). Instituto Dr. Luis Mora .

Flynn, D., y Giráldez, A. (1995). Arbitrage, China, and world trade in the early modern period. Journal of the Economic and Social History of the Orient/Journal de l'histoire economique et sociale de l'Orient, (12), pp. 429-448.

Flynn D. y Giráldez, A. (2002). Cycles of Silver: Global Economic Unity through the Mid-Eighteenth Century. Journal of World History , 13 (2), 391-427. Recuperado de https://www.jstor.org/stable/20078977.

Fradkin, R. y Garavaglia, J. C. (2016). El Río de la Plata durante el siglo XVIII. Producción y circulación en un mosaico de regiones. En J. C. Garavaglia, La Argentina colonial. El Río de la Plata entre los siglos XVI al XVIII (pp. 65-87). Siglo XXI.

Gelman, J. (1996). Don Domingo Belgrano Pérez, un gran comerciante de Buenos Aires y del Virreinato del Río de la Plata. En J. Gelman De mercachifle a gran comerciante : los caminos del ascenso en el Río de la Plata Colonial (pp. 25-41). Universidad Internacional de Andalucia.

Gervais, P. (2012). Mercantile credit and trading rings in the eighteenth century. Annales. Histoire, Sciences Sociales, 67 (4), pp. 693-730. https://doi.org/10.1017/S239856820000042X

Giménez López, E. (2019). Los altercados en Tucumán tras la expulsión de los Jesuitas. Chronica Nova, 45 (19), pp. 297-319. https://doi.org/10.30827/cn.v0i45.6768

Jumar, F. (2018). El mundo hispánico durante el Antiguo Régimen desde los circuitos mercantiles y el espacio económico rioplatense. Historia crítica, (70), pp. 23-44. http://dx.doi.org/10.7440/histcrit70.2018.02

Justiniano, M. F., Madregal, C. y Anachuri, G. (2019). Juan Antonio Moldes: De criado a comerciante global y funcionario regio (Salta, Buenos Aires, Cádiz, Filipinas, 1764-1804). Revista de Indias, 79 (276), pp. 433-457. https://doi.org/10.3989/revindias.2019.013

Kuz, A., Falco, M. y Giandini, R. (2016). Análisis de Redes Sociales. Un caso práctico. Computación y sistemas, 20 (1), pp. 1-23. https://doi.org/10.13053/cys-20-1-2321 
Lorandi, A. M. (2000). Las rebeliones indígenas. En E. Tándeter, Nueva Historia Argentina II (págs. 285-330). Buenos Aires: Sudamericana

Lorandi, A. M. (2008). Poder central, poder local. Funcionarios borbónicos en el Tucumán colonial. Un estudio de Antropología Política. Prometeo .

Marichal, C. (2017). De la plata a la cocaína. Cinco siglos de historia económica de América Latina, 1500-2000. Fondo de cultura económica .

Mata, S. (1991). Economía agraria y sociedad en los valles de Lerma y Calchaquí. Fines del siglo XVIII. Anuario IEHS: Instituto de Estudios histórico sociales, (6), pp. 67-89.

Mata, S. (1994). Los comerciantes de Salta a fines del siglo XVIII. Anuario de la Escuela de Historia,s/n, pp. 189-211.

Mata, S. (1996). El crédito mercantil. Salta finales del siglo XVIII. Anuario de estudios americanos, 53 (2), 147-171.

Mata, S. (2000). Tierra y poder en Salta: El noroeste argentino en vísperas de la independencia (pp. 27-52). Diputación de Sevilla.

Mata, S. (2005). Las fronteras coloniales como espacios de interacción social. Salta del Tucumán (Argentina), entre la Colonia y la Independencia. Dimensión Antropológica, (33), pp. 70-89.

Recuperado https://www.dimensionantropologica.inah.gob.mx/?p=1121

de:

Mir, J. L. (2013). Del censo a la obligación: La transformación de los mercados de crédito en el tránsito del antiguo régimen al estado liberal . Trabajo de investigación del máster en Historia Económica: UB-UAB-UZ.

Moreno, J. V. (2014). Tasas de interés y desempeño económico: el crédito comercial en Santafé de Bogotá, 1760-1810. América Latina en la Historia Económica, 21 (3), pp. 10-45. https://doi.org/10.18232/alhe.v21i3.577

Moutoukias, Z. (1996). Negocios y redes sociales modelo interpretativo a partir de un caso rioplatense (siglo XVIII). Cahiers du monde hispanique et luso-brésilien , (67), 37-55. Recuperado de: https://www.persee.fr/doc/carav_1147-6753_1996_num_67_1_2707 
Moutoukias, Z. (2015). Dependencias temporales y cambios institucionales en la América Hispánica a finales del siglo XVIII e inicios del siglo XIX. Historia Crítica (58), pp. 57-178. Recuperado de: http://www.scielo.org.co/scielo.php?script=sci_abstract\&pid=S0121$16172015000400009 \& \operatorname{lng}=$ en\&nrm=iso\&tlng=es

Quintanar, I. (2017). Una aproximacion al estudio de las redes crediticias novohispana: El consulado de la ciudad de Mexico y el depósito irregular, siglos XVIII-XIX. En G. d. Ibarra, Redes, corporaciones comerciales y mercados hispanoamericanos en la economia global, (pp. 157-199). Instituto Mora.

Ramos, M. V. (2013). Córdoba en la transición del orden colonial al período revolucionario: procesos políticos y conflictos. Síntesis, (4), pp. 1-19. Recuperado de https://revistas.unc.edu.ar/index.php/sintesis/article/view/12230/12559

Sánchez Albornoz, N. (1965). La saca de mulas de Salta al Perú, 17781808. Anuario del Instituto de Investigaciones Históricas, (8), pp. 263314.

Socolow, S. (1991). Los mercaderes del Buenos Aires virreinal: familia y comercio. Ediciones de La Flor.

Twinam, A. (2009). Vidas públicas, secretos privados. Género, honor, sexualidad e ilegitimidad en la hispanoamerica colonial (pp. 21-51). Fondo de cultura económica .

Vázquez, M. E. (1966). Ensayo sobre el crédito en Chile Colonial. Universidad de Chile .

Wasserman, M. (2014). Las formas de la palabra. Instrumentos públicos y privados para el compromiso económico en la génesis de un puerto iberoamericano. Revista Uruguaya de Historia Económica, IV (6), 1135.

Recuperado

de http://www.audhe.org.uy/images/stories/upload/Revista/Revista_6/wa sserman\%2011\%20a\%2035.pdf

Wasserman, M. (2016). Real Situado y gestión patrimonial del recurso fiscal. Remesas para la defensa del puerto de Buenos Aires en el siglo XVII. Nuevo Mundo Mundos Nuevos, pp. 1-19. https://doi.org/10.4000/nuevomundo.69317

Wasserman, M. (2018a). Impacto del gasto público sobre una economía hispanoamericana de Antiguo Régimen: Buenos Aires en el siglo 
XVII. Una aproximación desde el Análisis de Redes Sociales. Redes, 29 (1), pp. 139-162. https://doi.org/10.5565/rev/redes.731

Wasserman, M. (2018b). Las obligaciones fundamentales. Crédito y consolidación económica durante el surgimiento de Buenos Aires (pp. 167-187). Prometeo.

Wasserman, M. y Anachuri, G. (2020). Crédito, crisis y cambio institucional en una economía virreinal. Salta ante el reformismo borbónico, 17771786. Historia de América, https://doi.org/10.35424/rha.158.2020.595

(158)

pp.

41-72. 